\title{
NOTAS SOBRE O COMÉRCIO ELETRÔNICO E SUAS IMPLICAÇÕES NA REALIDADE JURÍDICA CONTEMPORÂNEA: UMA LEITURA INTERDISCIPLINAR ${ }^{1}$
}

\section{Christienne Krassuski Fortes}

Bacharel em Direito pela Universidade Federal do Paraná.

SUMÁRIO: Introdução; 1 Diretrizes gerais sobre comércio eletrônico; 2 A legislação sobre comércio eletrônico no contexto internacional; 3 A contratação eletrônica; Conclusão; Referências bibliográficas.

\section{INTRODUÇÃO}

A vida é dinâmica. Em instantes a realidade, rocha sólida, fragmenta-se e se transforma. Pedaços dessa rocha podem originar areia, diamante, ou... silício. O mundo passa por uma grande mudança estrutural, que está modificando velhos conceitos partes da "rocha" que por anos esteve fixa, inabalável, no mesmo lugar.

É uma mudança invisível e que por isso mesmo pode causar espanto nos mais incautos, surtir descrédito por parte dos mais conservadores, ou entusiasmo para quem possui espírito desbravador.

Trata-se da revolução que está surgindo graças ao advento do e-commerce, ou comércio eletrônico. Dessa nova faceta do comércio contemporâneo, inúmeras relações entrelaçam-se, necessitando de um cuidado maior por parte dos juristas, que muitas vezes questionam-se como proceder frente aos casos concretos que estão surgindo.

Há também as questões atinentes à regulamentação - ainda incipiente no Brasil - estando a legislação em um ritmo lento, se comparado ao das alterações vertiginosas que norteiam a realidade.

Pequenos traços desse novo tema - ainda em estado de construção doutrinária serão delineados a seguir.

O primeiro capítulo a ser estudado terá a exposição das diretrizes gerais sobre o comércio eletrônico. O primeiro tópico apontará o conceito de e-commerce nas áreas de maior evidência, como de comunicações, serviços e nas relações negociais em geral. A seguir, serão dispostas notas preliminares sobre as questões legais acerca desse tema, como o papel do direito comercial frente a essa nova realidade e os assuntos mais 
controvertidos envolvendo o comércio realizado no meio virtual. No terceiro ponto, situar-se-á o tema no panorama mundial, especialmente no que pertine à globalização.

No capítulo seguinte, haverá um detalhamento a respeito da legislação sobre o comércio eletrônico no contexto internacional. Inicialmente, será mostrado o papel da ONU e seus organismos, como a UNCITRAL, UNCTAD, OECD, OMC e OMPI, apresentando seus estudos mais relevantes, destacando-se a Lei Modelo sobre Comércio Eletrônico. A seguir, a União Européia e o comércio eletrônico serão objeto de análise, através das diretivas criadas para sua regulamentação. O terceiro tópico fará um breve relato sobre as leis ou projetos de lei concernentes ao e-commerce em diversos países, como Alemanha, Itália, França, Espanha, Portugal, Argentina, Peru, Colômbia, México, Japão e Estados Unidos, seguido pelo tópico que trata especificamente da situação legislativa brasileira em relação ao tema.

O último capítulo versará sobre as questões materiais pertinentes à contratação eletrônica. Serão expostas noções gerais sobre contrato eletrônico, em sede preliminar. A seguir, haverá um estudo acerca das espécies de contrato mais comuns no comércio eletrônico. Será dado um tratamento especial à contratação eletrônica internacional, no terceiro ponto desse capítulo. No tópico seguinte, será analisada a relação entre os contratos eletrônicos e o Código de Defesa do Consumidor. Por fim, dando fechamento à pesquisa, a controvertida questão da prova do contrato eletrônico será explicitada no último tópico do trabalho.

\section{DIRETRIZES GERAIS SOBRE COMÉRCIO ELETRÔNICO}

\subsection{Conceito}

São muitas as definições de comércio eletrônico, dependendo do ponto de vista da área em que é trabalhado: como não se trata de um conceito estático, é grande a dificuldade em delimitá-lo, gerando muitas complicações para quem pretende colocálo em uma moldura dogmática. "The definition is ever-changing and expanding to include more and more sectors of the economy, as the influence of electronic communications extends". ${ }^{2}$ Para restringir o objeto de estudo, estão colocadas aqui as noções de comércio eletrônico nas áreas em que ele é mais evidente.

KALAKOTA e WHISTON ${ }^{3}$ apresentam diversas definições para o comércio eletrônico. Para eles, de acordo com uma perspectiva da área das comunicações, é a entrega de informação, produtos e serviços por intermédio de redes de computador ou outros meios; já segundo uma perspectiva comercial, é a aplicação de tecnologia voltada para a automação de transações de negócios.

2 WHISTON et al. (The economics of electronic commerce, p. 12): "Essa definição está sempre mudando e expandindo para incluir mais e mais setores da economia, haja vista que a influência das comunicações eletrônicas está sendo ampliada".

3 KALAKOTA, Ravi; WHINSTON, Andrew B. Electronic commerce. A manager's guide. New York: Addison Wesley, 1999. 
Sob o ponto de vista da área de serviços, o comércio eletrônico é uma ferramenta que evidencia os anseios das firmas, consumidores e gerencia o corte de custos dos serviços, por meio do incremento da qualidade das mercadorias e do aumento da velocidade de sua entrega.

Visto por uma perspectiva mais ampla, comércio eletrônico poderia ser considerado como aquele que determina a capacidade de comprar e vender produtos e informações na Internet e a prestação de serviços on-line.

O comércio nesta nova era, à luz da presença da informática, é visto de uma nova maneira, já que se estende não só ao domínio dos aparelhos que possibilitarão o comércio, mas também ao domínio da transmissão de notícias e trocas de dados e informações.

Com o comércio eletrônico, a principal mudança é o fato de que é levada ao alcance do consumidor a "vitrine" do comerciante sem a necessidade de um deslocamento físico até um estabelecimento real.

Outras situações que decorrem desse novo modo de comerciar estão presentes nas operações financeiras subjacentes às transações que são efetuadas neste meio virtual.

Exemplos são os pagamentos em si e as operações bancárias tradicionais, tais como os descontos de duplicatas e faturas, transferências entre contas e as cobranças, que circulam pelo meio digital e realizam as tarefas que outrora eram realizadas pessoalmente, de modo mais rápido e eficaz. LUIZ OLAVO BAPTISTA, vislumbrando este contexto, chega até a afirmar, incisivamente, que: "A moeda escritural é, agora, digital e eletrônica". ${ }^{4}$

O comércio eletrônico é desenvolvido sob diversos aspectos, muitos deles dependendo do grau de digitalização do produto ou serviço prestado, o processo e o agente de entrega deste (ou o intermediário). Consoante o modelo tridimensional criado por $\mathrm{CHOI},{ }^{5}$ um produto pode ser físico ou digital, tanto como o agente e o processo.

No comércio tradicional, todas as dimensões são físicas; enquanto, no comércio eletrônico puro, todas são digitais. São muitas situações em que há uma mistura das duas formas de comerciar, em que há no mínimo uma situação como sendo de comércio eletrônico.

Um exemplo é o de um livro comprado através da Amazon. ${ }^{6}$ Não se trata de um comércio eletrônico puro, pois há entrega do livro por um agente real (nos EUA, a

4 BAPTISTA, Luiz Olavo. Comércio eletrônico: uma visão do Direito brasileiro. In: Revista da Faculdade de Direito da Universidade de São Paulo. São Paulo. Serviço Técnico de Imprensa, v. 94, p. 84, 1999.

5 WHISTON, Andrew B.; STAHL, Dale O.; CHOI, Soon-Yong. The economics of electronic commerce. Indianopolis: Macmillan Technical Publishing, 1997.

6 A Amazon é uma loja virtual surgida em 1995, nos Estados Unidos, objetivando a venda de livros online. Atualmente, é um dos maiores portais de venda de produtos pela Internet, possibilitando a compra de brinquedos, objetos domésticos, computadores, entre outros. Amazon.com. Disponível em: www.amazon.com. Acesso em: 23 out. 2002. 
FedEx). Um caso de comércio eletrônico puro seria a compra de um software da empresa virtual Egghead, por exemplo, em que tanto a entrega, como o modo de pagamento e o agente são digitais.

O e-commerce também se apresenta classificado, no meio empresarial, por um critério quanto à natureza da transação.

Segundo o entendimento corrente, a parte do comércio eletrônico contemporâneo que apresenta maior lucratividade é o chamado B2B, abreviação de business-to-business, composto pelas IOS (interorganizational information systems) - que envolve uma circulação de informações entre duas ou mais empresas, cujo maior objetivo é a transmissão de dados, mandatos, contas e pagamentos através de EDI (electronic data interchange, ou troca eletrônica de dados) ou extranets, sendo tais relações predeterminadas, com caráter exclusivamente executório -, e também pelas transações dos mercados eletrônicos entre organizações, sendo este mercado uma rede de relacionamento e interações em que informações, produtos e serviços são trocados quando o mercado é eletrônico, como já se ressaltou, o centro dos negócios não é uma construção física, mas uma rede embasada nestas interações, conduzindo todas as transações necessárias, como a transferência de dinheiro entre bancos.

Outra forma bastante recorrente de comércio eletrônico é a do B2C, ou businessto-consumer, um modo de venda a varejo realizado entre a empresa e o consumidor.

Além dessas, há também o $\mathrm{C} 2 \mathrm{C}$ (consumer-to-consumer), em que indivíduos vendem diretamente aos consumidores, em anúncios classificados pessoais, vendendo serviços e propriedades residenciais, carros, entre outros. Existe também o C2B (consumer-to-business), por meio do qual os indivíduos vendem produtos ou serviços a organizações.

Outra nota que marca o comércio eletrônico de forma incisiva é a da derrubada das fronteiras físicas no tocante às relações comerciais. Com o uso maciço da Internet, as operações econômicas podem ser realizadas independentemente do país em que estão localizados os destinatários.

\subsection{Questões legais: notas preliminares}

Devido a toda essa teia de novas relações que surgem com o comércio eletrônico, advêm diversos pontos controversos. Dessas transformações acabam por surgir fórmulas e modos de contratar ainda não contemplados na lei, mas que se tornam regras de força obrigatória na prática comercial, fato bastante coerente com a própria natureza do direito comercial.

No caso brasileiro, em particular, é sabido que a principal fonte específica desse ramo do Direito são as leis constantes do Código Comercial de 1850. Contudo, como ele é ultrapassado, necessita constantemente de leis esparsas para complementá-lo e para suprir as lacunas que surgem com as mudanças conjunturais. ${ }^{7}$

7 O exemplo mais atual é o advento do novo Código Civil, que unifica o direito privado, incluindo em seu bojo disposições relativas às obrigações, contratos e atividade econômica, criando o direito de 
Além dessa prática, como a atividade comercial possui um aspecto de dinamicidade, adotam-se também os usos e costumes preconizados pelo direito consuetudinário, cuja origem remonta à Idade Média e ao modo de proceder dos comerciantes da época. São práticas que surgem de modo espontâneo, cujas regras por ela fixadas tornam-se relações jurídicas que são observadas como regra de direito, não passíveis de violação.

É isso o que ocorre, via de regra, no mundo virtual regido pelo e-commerce, dada a dinamicidade que lhe é inerente: a auto-regulamentação, consubstanciada pela adoção de costumes.

Todavia, estão começando a se forjar leis no mundo inteiro, em uma tentativa de positivação, já que uma soma muito grande de dinheiro oriunda dessas relações está envolvendo empresas de grande porte, com alcance internacional, e um sem número de pessoas a elas vinculadas fazendo transações de toda espécie.

Sob um plano geral, podem ser enumeradas como sendo mais relevantes envolvendo o comércio eletrônico, as questões legais dispostas a seguir.

Um dos aspectos controversos, que está simbioticamente relacionado ao comércio eletrônico, é a validade da assinatura digital e dos contratos efetuados por meio eletrônico, que estão sendo cada vez mais disseminados nas relações comerciais, haja vista que as transações eletrônicas efetuadas pela rede formalizam-se em documentos informáticos que são fundamentais para a comprovação dos negócios jurídicos. Tamanha é a relevância desse assunto que a maior parte das leis editadas nos países que estão se preocupando com a positivação do comércio eletrônico trata em seus dispositivos da eficácia de tais documentos como meio legítimo de prova.

A tutela ao consumidor também surge como um dos pontos basilares. Muitas questões legais que se relacionam com a proteção dos consumidores, abrangendo de adulterações até diferentes tipos de fraude, estão relacionadas ao comércio eletrônico. A privacidade tem também se tornado uma das mais importantes questões que envolvem os consumidores. Outro ponto é o da liberdade de expressão, pelo fato de a Internet conceder a maior oportunidade já existente para tanto. Contudo, essa liberdade pode ofender outras pessoas, suscitando uma colisão de direitos.

Cabe ressaltar também o desafio da tutela à propriedade intelectual - que tem como maior foco os direitos autorais -, cuja proteção tem se tornado muito complicada pela Internet, visto que é fácil e pouco dispendioso copiar e disseminar informações digitalizadas. Além disso, há uma grande dificuldade em monitorar quem está usando a propriedade intelectual e como o faz.

A tributação do comércio eletrônico é outro assunto que demanda muita discussão. Atualmente, não há a imposição de novos tributos nos negócios feitos pela 
Internet. Em abstrato, cogita-se a possibilidade de ocorrer e as possíveis colisões entre as leis tributárias dos diferentes países.

Outros tópicos relacionados ao e-commerce são o da responsabilidade civil dos provedores de acesso, a jurisdição sobre as transações, as políticas de criptografia, os jogos de aposta e as questões éticas em si.

\subsection{Contextualização do problema: necessidade mundial de regulamentação}

O comércio eletrônico está envolvido em um contexto amplo de globalização, podendo-se até afirmar que se trata da globalização em todo seu esplendor, pois as fronteiras virtuais, em oposição ao conceito tradicional de soberania, desconhecem limites entre os países.

Entretanto, cabe ressaltar que o mundo virtual não é uma realidade à parte: ele é uma faceta - evidentemente, com características peculiares - do mundo real. Isso implica a necessidade de haver uma regulamentação acerca de algumas atividades circunscritas ao comércio efetuado eletronicamente - não abarcadas pela legislação em vigor e também de tratamento especial a determinadas matérias que, embora possam estar abrangidas pela lei já existente, possuem certas nuanças que não se encontram nas situações que lhe são correlatas fora do meio virtual.

Assim sendo, vários países procuraram desenvolver leis específicas sobre o comércio eletrônico - a primeira delas, pontue-se, é o Digital Signature Act, do Estado americano de Utah, datada de novembro de 1995. A maior parte das leis segue como padrão norteador uma lei modelo desenvolvida pela UNCITRAL, sigla da United Nations Commission on Internacional Trade Law, ou Comissão das Nações Unidas de Direito Comercial Internacional.

\section{A LEGISLAÇÃO SOBRE O COMÉRCIO ELETRÔNICO NO CONTEXTO INTERNACIONAL}

\subsection{O papel da ONU e seus organismos}

A UNCITRAL, criada pela Assembléia-geral da ONU em 1966, facilita o comércio mundial desenvolvendo convenções, leis-modelo, regras e guias legais criados para harmonizar a leis internacionais de comércio. ${ }^{8}$

Por intermédio de diversas conferências realizadas pelos países integrantes da ONU, houve a discussão acerca dos inúmeros aspectos legais pertinentes ao e-commerce, destacando a importância do comércio eletrônico como um veículo para promover a participação dos países em desenvolvimento no comércio global e a necessidade das 
questões relativas a esse âmbito do comércio serem dirigidas e monitoradas de modo homogêneo.

Esse segundo ponto justificar-se-ia para a remoção de impedimentos legais aos meios de comunicação eletrônicos no comércio internacional que acabam por atravancar o livre desenvolvimento das relações mercantis.

A preocupação das Nações Unidas sobre essa regulamentação teve início em 1985, quando a UNCITRAL convidou todos os governos a revisar o conceito legal de obrigatoriedade dos documentos serem assinados à mão, ou por outro meio baseado apenas no papel, a fim de que houvesse também permissão do uso de meios eletrônicos de autenticação quando fosse apropriado, tendo sido essa recomendação endossada pela Assembléia-geral da ONU ( $§ 5^{\circ}$ da Resolução 40/71 da Assembléia-geral, de 11 de dezembro de 1985).

A UNCITRAL continuou a monitorar a área de troca eletrônica de dados (electronic data interchange - EDI), devido à permanência da obrigatoriedade de que os documentos fossem baseados apenas em papel, combinados com a ausência de harmonização entre as regras aplicáveis ao comércio eletrônico, que se constituía em uma barreira para o comércio internacional, surtindo a necessidade de regras uniformes para o e-commerce.

Em 1992, a UNCITRAL procedeu à preparação de regras legais sobre o assunto, e sua aprovação final resultou na Lei Modelo sobre o Comércio Eletrônico (Model Law on Electronic Commerce), em 14 de julho de 1996. Logo após, em dezembro do mesmo ano, ela foi adotada pela Assembléia-geral. ${ }^{9}$

Além da UNCITRAL, outros organismos da ONU estão envolvidos com as novas questões tecnológicas, destacando-se o papel da UNCTAD (United Nations Conference on Trade and Development, ou Conferência das Nações Unidas sobre Comércio e Desenvolvimento). Ela foi criada em 1964 para acelerar o comércio e o desenvolvimento econômico, em particular nos países em desenvolvimento. "UNCTAD is the focal point within the United Nations system for the integrated treatment of development and interrelated issues in the areas of trade, finance, technology, investment and sustainable development ${ }^{\prime} .{ }^{10}$ Entre as funções da UNCTAD, atualmente, está a

9 Os principais temas disciplinados pela Lei Modelo são a definição de mensagem eletrônica, transmissão eletrônica de dados, remetente, destinatário, intermediário e sistema de informação; questões interpretativas; reconhecimento jurídico das mensagens eletrônicas; equiparação plena do escrito eletrônico ao convencional, salvo na questão da assinatura eletrônica, que para preencher o requisito de validade necessita de métodos técnicos de identificação; a conservação da mensagem em sua forma original, sem modificações posteriores; admissibilidade de força probante às mensagens de dados, às quais não deve ser colocado nenhum óbice tão-somente pela sua natureza eletrônica; validade dos contratos eletrônicos e assuntos relacionados; transporte de mercadorias.

10 Basic facts about the United Nations. New York: United Nations, 1998, p. 35: "UNCTAD é o foco principal dentro do sistema das Nações Unidas para o tratamento integrado do desenvolvimento e questões inter-relacionadas nas áreas do comércio, finanças, tecnologia, investimento e desenvolvimento sustentável". 
promoção global do comércio eletrônico, facilitando o acesso às tecnologias da informação, particularmente através de seu Global Trade Point Programme. ${ }^{11}$

No ano de 1998, a secretaria da UNCTAD lançou um estudo intitulado: Electronic commerce: legal considerations (Comércio eletrônico: considerações legais), que revisou muitas das questões em relevo nas regras legais baseadas no papel, como o requerimento de documento escrito, assinado e original.

Esse estudo evidenciou o valor das mensagens eletrônicas, o armazenamento dessas mensagens, documentos de título e comerciais, partilha de obrigações, validade e formação de contratos e sua incorporação como referência. Muitas dessas questões foram levantadas em estudos prévios, realizados pela United Nations Economic Commission for Europe (ECE) - Comissão das Nações Unidas para a Europa, que propuseram instrumentos nacionais e internacionais, sendo o mais significativo deles a Lei Modelo sobre o Comércio Eletrônico, que fora citada supra.

A Lei Modelo (ou Lei-Tipo, que é um modelo de lei que facilita a elaboração de leis internas) tem como objetivo principal oferecer aos legisladores nacionais uma série de regras internacionalmente aceitáveis, permitindo a remoção de obstáculos legais, proporcionando um ambiente legal seguro para o comércio eletrônico, e tem como âmbito de aplicação qualquer tipo de informação na forma de mensagem de dados usada no contexto de atividades comerciais. Juntamente com a lei, há também um guia para sua decretação com o fito de ajudar os legisladores e usuários, fornecendo explicações sobre a Lei Modelo.

A Lei Modelo enumera alguns princípios-chave. O primeiro deles é o da nãodiscriminação, exposto em seu art. $5^{\circ}$, em que: "Não se negarão efeitos jurídicos, validade ou eficácia à informação apenas porque esteja na forma de mensagem eletrônica". Para dar efetividade a esse princípio, a lei apresenta regras que definem quais seriam os equivalentes ao documento escrito, à assinatura e ao original no ambiente eletrônico, assim como mostra regras governando a admissibilidade e o peso evidente das mensagens eletrônicas, a retenção de dados das mensagens, a formação e a validade dos contratos e atribuições.

Desde sua adoção, a Lei Modelo tem sido usada como um parâmetro para muitos países, considerada como uma resposta apropriada às questões relativas ao e-commerce. Uma quantidade razoável de países recentemente apresentou, ou está na iminência de apresentar, leis que acolhem a Lei Modelo ou que a ela se remetem, pois se presta a auxiliar em algumas questões, pelo fato de já terem sido nela relatadas sugestões para saná-las.

Segundo dados da Comissão das Nações Unidas de Direito Comercial Internacional, atualizados em 22 de setembro de 2002, este é o status da Lei Modelo 
sobre o comércio eletrônico: legislações baseadas na Lei Modelo foram adotadas na Austrália, Colômbia, Equador, França, México, Irlanda, Coréia, Singapura, Eslovênia, Hong Kong, entre outros. Nos EUA, foi adotada integralmente pelo Estado de Illinois. Uma legislação uniforme, cujos princípios tiveram influência direta da Lei Modelo da UNCITRAL, foi preparada no Canadá (Uniform Electronic Commerce Act, adotada em 1999) e nos EUA (Uniform Electronic Transations Act, também adotada em 1999), sendo acolhida integralmente como lei por vários estados desses países. ${ }^{12}$

Alguns países criaram grupos políticos de trabalho, consultando em alguns casos o setor privado, que estão trabalhando a necessidade de mudanças legislativas para facilitar o comércio eletrônico, considerando a adoção da Lei Modelo, preparando a legislação necessária e trabalhando nas questões da assinatura eletrônica.

Ademais, complementando a Lei Modelo, a UNCITRAL continuou com seu trabalho de preparação de standards legais, prosseguindo na área de assinaturas digitais e autoridades certificadoras. Acordou-se que as leis uniformes deveriam conceder um suporte legal aos processos de certificação, aplicabilidade desse processo, proporção de risco e endividamento entre os usuários, fornecedores e terceiros, e o uso de registros equivalentes aos cartoriais no processo de certificação.

Consoante essa perspectiva, a fim de proporcionar maior segurança a respeito desse tema, em 2001 a UNCITRAL apresentou a Lei Modelo sobre Assinaturas Eletrônicas (UNCITRAL Model Law on Electronic Signatures), estabelecendo que as assinaturas digitais deveriam ser consideradas como equivalentes às manuscritas, bem como regras básicas de conduta a serem observadas pelas partes envolvidas no processo da assinatura eletrônica.

Outra organização internacional que se dedicou às questões legais pertinentes ao comércio eletrônico foi a OECD (Organization for Economic Co-operation and Development, ou Organização para a Cooperação Econômica e Desenvolvimento).

A OECD agrupa vinte e nove países-membros em uma organização que, prioritariamente, fornece aos governos parâmetros para discutir, desenvolver e aperfeiçoar a economia e a política social, comparando experiências, procurando respostas a problemas comuns e trabalhando para coordenar a política interna e internacional. Assim, oferece uma chance para os governos de refletir e trocar perspectivas com outros países em situação similar.

Os países da OECD somam dois terços da produção mundial de mercadorias e serviços, sendo compostos pelos países da Europa, América do Norte, incluindo também Japão, Austrália, Nova Zelândia, Finlândia, Polônia, Coréia, entre outros.

As trocas entre os países da OECD circulam através de informação e análise oriundos de um secretariado em Paris. Partes desse secretariado juntam informações, 
acompanham tendências, analisam e prevêem taxas de desenvolvimento econômico, enquanto outras pesquisam mudanças sociais ou padrões desenvolvidos no comércio, meio ambiente, agricultura, tecnologia, taxação.

Esse trabalho é feito sob a orientação dos mentores do planejamento político e dos moldes de ação dos governos, os quais se utilizam da análise e valem-se da discussão feita com os países-membros nos encontros dos comitês especializados da OECD.

Primeiramente, a OECD enfocou o impacto social e econômico do comércio eletrônico. Em 1998, lançou suas primeiras descobertas e agendou a pesquisa na área. O relatório originado desses estudos preliminares destacou que o comércio eletrônico transforma o mercado, tendo um efeito catalítico, aumentando amplamente a interatividade na economia, sendo caracterizado pela abertura e expansão, modificando o valor do tempo.

Esse relatório destacou, ainda, que as forças condutoras do e-commerce requerem um reexame da moldura com que os negócios são conduzidos, colocando também um questionamento acerca da eficácia das políticas governamentais pertinentes aos tradicionais costumes e administração do comércio, engendrados por meio de uma imagem completamente diferente de comércio, oriunda de outro contexto.

Em outubro do mesmo ano, conjuntamente com o governo do Canadá, a OECD apresentou uma conferência ministerial conhecida como: "Um mundo sem fronteiras: descobrindo o potencial do comércio eletrônico global", também conhecida como a Conferência de Ottawa. Essa conferência reuniu líderes de governos nacionais e interesses sociais, de consumidores e trabalhadores, discutindo um plano global de ação para o comércio eletrônico.

Declarações surgidas por meio de conferências como essa burilaram as pesquisas acerca de privacidade, proteção ao consumidor, impacto socioeconômico, autenticação, além de vários acordos e um plano de trabalho sobre a tributação.

O plano de ação da OECD foi organizado em quatro linhas temáticas: a formação de confiança para os usuários e consumidores, o estabelecimento de regras básicas para o mercado digital, o aumento da infra-estrutura de informação sobre o e-commerce e a maximização dos benefícios do comércio eletrônico. Na época, a ausência de uma base legal sólida foi considerada um dos maiores empecilhos para o alcance desse intento.

Além da UNCITRAL e da OECD, a OMC (Organização Mundial do Comércio), também conhecida por WTO (World Trade Organization), tem implementado esforços de seus membros para devassar detalhes acerca do comércio eletrônico. A OMC está, em sua essência, voltada para a consecução de um objetivo primordial, que é versar sobre regras a respeito do comércio global entre as nações e com elas assegurar que ele circule da forma mais livre possível, por intermédio de uma participação mais efetiva dos países em desenvolvimento no comércio internacional. 
Suas funções, expostas no acordo constitutivo, são administrar e aplicar os acordos comerciais multilaterais e plurilaterais que em conjunto configuram o novo sistema de comércio; servir de foro para as negociações multilaterais; administrar o entendimento relativo às normas e procedimentos que regulam as soluções de controvérsias; supervisionar as políticas comerciais nacionais e cooperar com as demais instituições internacionais que participam do fomento de políticas econômicas em nível mundial - FMI, BIRD e organismos conexos.

Especificamente em relação ao e-commerce, já em vinte de maio de 1998, na segunda Conferência Ministerial de Genebra, foi adotada por seus membros uma declaração sobre comércio eletrônico. Essa declaração, que foi dirigida ao Conselhogeral da OMC e por ele adotada em vinte e cinco de setembro de 1998, procurava estabelecer um substancial programa de trabalho, que examinava todas as questões comerciais que emergiam do e-commerce, sendo o ponto de maior destaque a afirmação de que os membros iriam continuar com a política atual de não-imposição de taxas alfandegárias no comércio eletrônico.

Entre os anos de 1999 e 2000, os relatórios apresentados ao Conselho Geral apresentaram alguns pontos-chave relativos a esse tema. Entre eles, está a identificação de três tipos de transações pela Internet: as que ocorrem inteiramente no meio virtual, as que envolvem serviços de distribuição de produtos, sejam mercadorias ou serviços, e, por fim, a transação que envolve serviços de telecomunicações, incluindo os provedores de acesso à Internet.

Em 2002, a OMC continua seguindo as diretrizes da Declaração de 1998. Um de seus últimos trabalhos ocorreu em 22 de abril, com a apresentação de um seminário em Genebra cujas linhas gerais englobavam o comércio eletrônico no contexto geral de trabalho da OMC, sua evolução e tendências, os efeitos da tributação na Internet como fonte geradora de recursos, bem como as experiências governamentais e do setor privado nesse novo setor da economia. ${ }^{13}$

No que diz respeito especificamente à tutela da propriedade intelectual no ambiente do comércio eletrônico, outro segmento da ONU tem direcionado seus esforços. Trata-se da WIPO, World Intellectual Property Organization, mais conhecida no Brasil como OMPI (Organização Mundial da Propriedade Intelectual), criada em 1970, cujo objetivo primordial é promover a proteção desse tipo de propriedade - que abrange invenções, design, marcas, livros, criações musicais, filmes - em todo o mundo.

Em setembro de 1999, a OMPI lançou, na WIPO International Conference on Electronic Commerce and Intellectual Property (ou Conferência Internacional sobre Comércio Eletrônico e Propriedade Intelectual da OMPI) um programa de trabalho intitulado Digital Agenda, que busca especialmente a formulação de respostas apropriadas para encorajar a disseminação e o uso da propriedade intelectual na Internet, bem como assegurar a proteção aos direitos autorais. 
Esse programa também procura ajustar a aplicação das leis de propriedade intelectual nas transações realizadas via Internet e o surgimento de novas leis relativas a esse assunto. Há uma grande ênfase em duas questões: a da validade dos contratos eletrônicos e a da competência entre as jurisdições, em um âmbito internacional.

Dois anos após, em setembro de 2001, foi realizada a WIPO Second International Conference on Electronic Commerce and Intellectual Property (ou Segunda Conferência Internacional sobre Comércio Eletrônico e Propriedade Intelectual da OMPI), que tratou das novidades nessa área, discutindo temas como marcas na Internet, publicações eletrônicas, músicas on-line, entre outros.

Cabe ressaltar, porém, que devido à ausência de sanções comerciais contra violações na área de propriedade intelectual no âmbito da OMPI, houve certa insistência por parte dos Estados Unidos para a assinatura de um acordo relativo à propriedade intelectual, conhecido por TRIP's, acordo do qual o Brasil também é signatário, firmado no GATT, na Rodada do Uruguai, fazendo com que questões de propriedade intelectual migrassem também para a OMC.

Todavia, saliente-se que a OMPI permanece sendo o órgão basilar da ONU para os assuntos concernentes aos direitos autorais e conexos.

\subsection{A União Européia e o comércio eletrônico}

A União Européia, com o intuito de mitigar o problema da regulamentação no âmbito comunitário, acabou por tomar a iniciativa de estabelecer diretivas pertinentes ao comércio eletrônico. Diretivas são fontes formais secundárias do direito comunitário - as primárias são os tratados - que são produzidas no âmbito das instituições comunitárias. Em 1998 houve a criação da primeira diretiva, a Diretiva 98/27/CE, que já ressaltava que:

"El comercio electrónico, en todas sus manifestaciones, es ya una realidad que atrae cada vez un mayor número de usuarios. Entre otras ventajas, las operaciones llevadas a cabo de este modo permiten reducir notablemente los costes de transacción y posibilitan al gran público un mercado de ámbito planetario, reduciendo en gran medida los inconvenientes derivados de las distancias geográficas. La Unión Europea, sensible a esta evolución, trabaja en la elaboración de una directiva que sirva de marco a la legislación de los Estados miembros." 14

14 União Européia, Directiva 98/27/CE (apud SÁNCHEZ, Guilhermo Ormazábal. La prueba documental y los médios e instrumentos idoneos para reproducir imagenes o sonidos o archivar y conocer dados. Coleccion ley de enjuiciamiento civil 2000. Madri: La Ley, 2000, p. 163.): "O comércio eletrônico, em todas suas manifestações, já é uma realidade que atrai cada vez um maior número de usuários. Entre outras vantagens, as operações levadas a cabo por esse meio permitem reduzir notavelmente os custos de transação e possibilitam ao grande público um mercado de âmbito planetário, reduzindo bastante os inconvenientes derivados das distâncias geográficas. A União Européia, sensível a essa evolução, trabalha na elaboração de uma diretiva que sirva de marco à legislação dos Estados-membros". 
A segunda diretiva data de 8 de junho de 2000 e foi elaborada em Luxemburgo. Trata-se da Diretiva 2000/31/CE, relativa aos aspectos legais dos serviços da sociedade de informação, em especial do comércio eletrônico, no mercado interno, cujos destinatários são os Estados-membros.

Tais Estados deveriam pôr em vigor as disposições necessárias para dar cumprimento à diretiva até 17 de janeiro de 2002, a fim de cumprir seu objetivo de "criar um enquadramento legal destinado a assegurar a livre circulação dos serviços da sociedade da informação nos Estados-membros". ${ }^{15}$

$\mathrm{Na}$ própria diretiva - que busca garantir a segurança jurídica e a confiança do consumidor por intermédio do estabelecimento de um quadro geral claro, que abranja aspectos legais do comércio eletrônico no mercado interno - acentua-se a necessidade de tal enquadramento:

"O desenvolvimento dos serviços da sociedade da informação na comunidade é entravado por uma série de obstáculos legais ao bom funcionamento do mercado interno, os quais, pela sua natureza, podem tornar menos atraente o exercício da liberdade de estabelecimento e a livre prestação de serviços. Esses obstáculos advêm da divergência das legislações, bem como da insegurança jurídica dos regimes nacionais aplicáveis a esses serviços." ${ }^{16}$

Em linhas gerais, a Diretiva 2000/31/CE trata de vários pontos relevantes para o desenvolvimento do e-commerce. Ela começa, em seu Capítulo I, a pontuar seu objetivo e âmbito de aplicação, passando a dispor, logo em seguida, as definições de termos como prestador de serviços e consumidor, para efeitos da diretiva. Após essas considerações iniciais, há a exposição das medidas a serem tomadas no mercado interno.

No Capítulo II, Seção I, são apresentados os princípios concernentes ao regime de estabelecimento e de informação. $\mathrm{O}$ art. $4^{\circ}$ trata do princípio de não-autorização prévia, em que os Estados-membros asseguram que o exercício e a prossecução da atividade de prestador de serviços da sociedade da informação não podem estar sujeitos a autorização prévia ou a qualquer outro requisito de efeito permanente, enquanto o art. $5^{\circ}$ trata das informações gerais a prestar - por meio das quais os Estados-membros asseguram que o prestador de serviços faculte aos destinatários do seu serviço um acesso fácil, direto e permanente a informações como o nome do prestador, o endereço geográfico em que ele se encontra estabelecido, elementos de informação relativos a ele que permitem contactá-lo diretamente e comunicar-se direta e efetivamente com ele, entre outras.

Já a Seção II diz respeito às comunicações comerciais. $\mathrm{O}$ art. $6^{\circ}$ fala das informações a prestar, enquanto o $7^{\circ}$ abrange o âmbito da comunicação comercial não solicitada. $\mathrm{O}$ art. $8^{\circ}$ é referente às profissões regulamentadas.

15 Comunidade Européia. Diretiva 2000/31/CE do Parlamento Europeu e do Conselho. Jornal Oficial das Comunidades Européias, 17 jul. 2000, p. 2.

16 Ibidem, p. 1. 
A Seção III engloba os contratos celebrados por meios eletrônicos, seu regime, as informações a serem prestadas e a ordem de encomenda. Em seguida vem a Seção $\mathrm{IV}$, referente à responsabilidade dos prestadores intermediários de serviços, nos casos de simples transporte, de armazenagem temporária - caching, armazenagem em servidor e os casos de ausência de obrigação geral de vigilância.

O Capítulo III refere-se à aplicação da diretiva. Menciona a necessidade de código de conduta a ser seguido, ressalta a importância de formas de resolução extrajudicial de litígios e, nos casos em que esta não é possível, necessitando o uso de ações judiciais, que haja uma rápida adoção de medidas destinadas a pôr termo às infrações alegadas, evitando prejuízo das partes interessadas.

Ressaltou-se o mister de existir uma cooperação entre os Estados-membros nesse âmbito, e também que as sanções previstas nos ordenamentos internos sejam "efetivas, proporcionadas e dissuasivas".

Persistindo na legislação concernente a assuntos conexos ao comércio eletrônico, a União Européia desenvolveu mais uma diretiva, agora relativa à privacidade e à comunicação eletrônica, que entrou em vigor em 31 de julho de 2002, devendo os Estados-membros se adequarem a ela até 31 de outubro de 2003. Essa diretiva se refere à proteção dos dados pessoais que circulam na Internet, especialmente para coibir a prática do spam, que consiste no envio de mensagens comerciais em massa para os $e$ mails dos consumidores sem sua prévia autorização.

Com a entrada em vigor dessa legislação no âmbito comunitário, além da necessidade de autorização por parte do consumidor para o recebimento de propaganda via e-mail, deverá haver autorização também para o uso de recursos de rastreamento no computador, como os cookies.

Os cookies são arquivos de texto que atribuem ao computador um código de identificação, que se presta ao reconhecimento do micro. É um recurso bastante utilizado em sites que realizam comércio eletrônico, pois através dele é possível obter, por exemplo, informações acerca dos sites visitados e vender esses dados a anunciantes que desejam fazer propaganda on-line de seus negócios. ${ }^{17}$ Essa diretiva, portanto, busca tutelar a privacidade dos consumidores, coibindo tal prática bastante comum no ambiente do comércio eletrônico, que é a da propagação indiscriminada de dados pessoais dos consumidores por parte das empresas virtuais, com o intuito de alavancar seus negócios.

Cabe mencionar também, como peça fundamental no âmbito do trabalho de harmonização do direito comunitário nas questões relativas ao comércio eletrônico, a Diretiva 2001/29/CE de 22 de maio de 2001, que trata do enquadramento legal dos direitos autorais e conexos na Internet por parte dos Estados-membros, devendo ser adotada pelos ordenamentos internos até 22 de dezembro de 2002. 


\section{$2.3 \mathrm{O}$ reflexo do e-commerce em contexto global}

Por intermédio desses organismos internacionais, começou a se formar uma consciência mundial, relativa não apenas à necessidade de regulamentação do comércio eletrônico, mas também às diretrizes básicas, ao modo com que se deveria proceder frente aos temas relativos a esse assunto.

Prioridades foram estabelecidas, e através delas os legisladores de diversos países conduziram seus trabalhos, como primeiras luzes a esclarecer os pontos obscuros de um ambiente que, dado seu ineditismo, ainda está em estado de criação. E não poderia ser de modo diferente com as leis, espelhos que são da realidade social da época em que são forjadas: a conjuntura, alterada, reclama um direito capaz de tutelá-la.

A título exemplificativo, serão colocados a seguir apontamentos sobre algumas leis pioneiras no contexto internacional. Cabe destacar, preliminarmente, na Europa, a iniciativa da Alemanha, que instituiu uma lei sobre assinatura digital em 1997, a Signaturverordnung - SigV (Digital Signature Ordinance, ou Lei das Assinaturas Digitais) e da Itália - Legge 15 marzo 1997, n 59, e Decreto n ${ }^{\circ}$ 513, de 10 de novembro de 1997, que também instituiu leis que dispõem sobre assinaturas eletrônicas.

A Grã-Bretanha, posteriormente - 25 de maio de 2000, criou uma lei sobre as comunicações eletrônicas chamada Electronic Communications Act 2000 (Lei de Comunicações Eletrônicas 2000), que em sua primeira parte dispõe sobre os fornecedores de serviços de criptografia; na segunda, que tem como título Facilitation of Electronic Commerce, Data Storage, etc. (Auxílio ao Comércio Eletrônico, Armazenamento de Dados, etc.), destaca-se a regulamentação das assinaturas eletrônicas e certificados a elas relacionados e, por fim, uma terceira parte suplementar. No preâmbulo dessa lei, estão dispostos os objetivos a que se propõe: "An Act to make provision to facilitate the use of electronic communications and electronic data storage; (...) and for connected purposes". ${ }^{18}$ No ano de 2000 foi editado um decreto para conceder eficácia às Seções 7, 11 e 12 a partir de 25 de julho do mesmo ano, salientando também que a primeira parte dessa lei ainda não entrara em vigor.

$\mathrm{Na}$ França, acompanhando essa tendência européia, foi enviado em 29 de outubro de 1998 um anteprojeto de lei - Avant-Project de Loi Relative a L'Activité d'Autorités de Certification Agrées em vue de L'Utilisation de Signatures Digitales (Anteprojeto de Lei Relativo à Atividade das Autoridades de Certificação Admitidas em Face da Utilização de Assinaturas Digitais) - concernente à adaptação do direito de prova às novas tecnologias, texto esse que dispunha sobre assinatura eletrônica, explicitando as noções de prova literal e assinatura, reconhecendo expressamente o valor jurídico do escrito e da assinatura sob a forma eletrônica e reconhecendo indiretamente a validade das convenções sobre a prova, organizando um regulamento para os conflitos entre as provas literais.

18 "Uma lei a fim de fornecer meios para facilitar o uso de comunicações eletrônicas e armazenamento de dados eletrônicos (...) e para propósitos conexos." 
MARYLINE DURIN destacou essa revolução, quando da época em que o anteprojeto fora convertido em Projeto de Lei pelo governo francês, em $1^{\circ}$ de setembro de 1999: "Le projet de loi adopté par le gouvernement le ler septempre 1999 constitue assurément une avancée considérable de la France dans l'ére des technologies de l'information". ${ }^{19}$

Após algumas alterações, em seção pública realizada em 29 de fevereiro de 2000 , o projeto de lei decorrente do anteprojeto supracitado teve sua aprovação na Assembléia Nacional francesa. É a Loi n. 2000-230 du 13 mars 2000 portant adaptation $d u$ droit de la preuve aux technologies de l'information et relative à la signature électronique (Lei ${ }^{\circ} 2000-230$ de 13 de março de 2000, contendo adaptação do direito de prova relativo às tecnologias da informação e à assinatura eletrônica).

Esse texto alterou dispositivos do Código Civil francês, relativos aos meios probatórios, adequando-os à nova realidade. ${ }^{20}$ Um exemplo é a inserção do inciso 3 no art. 1326 do Código: " $L$ 'écrit sur support électronique a la même force probante que l'écrit sur support papier", que confere ao escrito sobre suporte eletrônico o mesmo valor probante do escrito sobre papel.

A Espanha é outro país que está em processo de inovação legislativa. Em 1999 começou a trabalhar de modo mais contundente na positivação do comércio eletrônico, por intermédio do Real Decreto Ley 14/1999, que tratava da firma eletrônica, baseandose no projeto que consubstanciaria, mais tarde, a Diretiva 2000/31/CE.

Cabe mencionar, no caso espanhol, a nova Ley de Enjuiciamento Civil - a LEC 2000 (Código de Processo Civil espanhol), que teve como uma de suas maiores novidades em matéria probatória os incisos 2 e 3 de seu art. 299.

"1. Los medios de prueba de que se podrá hacer uso en juicio son: (...)

2. También se admitirán, conforme a lo dispuesto en esta Ley, los medios de reproducción de la palabra, el sonido y la imagen, así como los instrumentos que permiten archivar y conocer o reproducir datos, cifras y operaciones matemáticas llevadas a cabo con fines contables o de otra clase, relevantes para el proceso.

3. Cuando por cualquier otro medio no expresamente previsto en los apartados anteriores de este artículo pudiera obtenerse certeza sobre hechos relevantes, el Tribunal, a instancia de parte, lo admitirá como prueba, adoptando las medidas que en cada caso resulten necesarias."21

19 MARYLINE DURIN (apud LUCCA, Newton de. Títulos e contratos eletrônicos: o advento da informática e seu impacto no mundo jurídico. In: Direito e Internet - aspectos jurídicos relevantes. Bauru: EDIPRO, 2000, p. 80.): "O projeto de lei adotado pelo governo em $1^{\circ}$ de setembro de 1999 constitui certamente um avanço considerável da França na era das tecnologias da informação".

20 "O documento escrito tem a mesma força probante, seja sobre suporte eletrônico, seja sobre suporte de papel". Legifrance. Le service public de la diffusion du droit. Disponível em: www.legifrance.gouv.fr. Acesso em: 12 jul.2002.

21 SÁNCHEZ, Guilhermo Ormazábal. La prueba documental y los médios e instrumentos idoneos para reproducir imagenes o sonidos o archivar y conocer dados. Coleccion ley de enjuiciamiento civil 
Os preceitos oriundos desse artigo acabaram por converter o ordenamento processual civil espanhol em um dos mais modernos, pois adequou o Direito aos progressos científicos experimentados no âmbito das novas tecnologias da informação. SÁNCHEZ, em sua obra La prueba documental y los médios e instrumentos idoneos para reproducir imagenes o sonidos o archivar y conocer dados, inclusive, ressalta que: "Al introducir estos preceptos, el legislador español no há hecho outra cosa que reflejar y atender a una imponente evolución de la tecnología, singularmente en el ámbito de la información y de las telecomunicaciones, que está produciendo profundísimos efectos en numerosos ámbitos de relación social especialmente relevantes para el Derecho".22

Além disso, objetivando a integral incorporação ao ordenamento jurídico espanhol da Diretiva 2000/31/CE, e a Diretiva 98/27/CE no que se refere à proteção dos consumidores, há um projeto de lei que regulamenta o comércio eletrônico no país, Proyeto de ley de servicios de la sociedade de la información y de comercio electrónico (Projeto de lei de serviços da sociedade da informação e de comércio eletrônico), datado de 2 de fevereiro de 2002.

Em Portugal também está havendo uma movimentação no sentido de criar regras para acompanhar o progresso tecnológico nas relações comerciais. A fim de alcançar esse intento, houve o estabelecimento da Iniciativa Nacional para o Comércio Electrónico (INCE), aprovada pela Resolução do Conselho de Ministros n ${ }^{\circ}$ 115/98.

No âmbito dessa iniciativa, que objetiva a formulação de textos legislativos capazes de criar condições favoráveis ao desenvolvimento do comércio eletrônico, especialmente no que concerne à segurança, a Resolução $n^{\circ} 115 / 98$ determinou a definição do regime jurídico aplicável aos documentos eletrônicos e à assinatura digital, necessários à plena afirmação do e-commerce.

Para dar maior efetividade à iniciativa, adveio, em 25 de agosto de 1999, a Resolução ${ }^{\circ}$ 94/99, aprovando o Documento Orientador da INCE. Esse documento contempla um conjunto de princípios determinantes para a criação de um quadro favorável ao desenvolvimento do comércio eletrônico em Portugal, prevendo também medidas concretas. A resolução confere, a diversos membros do governo, tarefas específicas para a concretização dessas medidas e objetivos.

2000, Madri: La Ley, 2000, p. 161. “1. Os meios de prova de que se poderá fazer uso em juízo são (...). 2.Também admitir-se-ão, conforme o disposto nesta lei, os meios de reprodução da palavra, som e imagem, assim como os instrumentos que permitam arquivar e conhecer ou reproduzir dados, cifras e operações matemáticas executadas com fins contábeis ou de outra espécie, relevantes para o processo. 3. Quando por qualquer outro meio não expressamente previsto nos incisos anteriores deste artigo puder obter-se certeza sobre fatos relevantes, o tribunal irá admiti-lo como prova, adotando as medidas que sejam necessárias para cada caso".

22 Idem, ibidem, p. 162. "Ao introduzir esses preceitos, o legislador espanhol não fez outra coisa se não refletir e atender a uma importante evolução da tecnologia, em especial no âmbito da informação e das telecomunicações, que está produzindo profundíssimos efeitos em numerosos âmbitos de relação social especialmente relevantes para o Direito". 
A seguir foi estabelecido o Decreto-Lei n ${ }^{\circ} 290-\mathrm{D} / 99$, elaborado no quadro da iniciativa. O regime jurídico que foi instituído pelo decreto define regras-base sobre os documentos eletrônicos, procura resolver as questões de direito probatório material quanto ao valor de tais documentos, condicionando sua validade à aposição de uma assinatura digital.

No mesmo ano, o Decreto-Lei $n^{\circ}$ 375/99 estabeleceu a equiparação entre a fatura emitida em suporte de papel e a fatura eletrônica, prevendo as condições em que essa equiparação dar-se-ia. No ano seguinte, em 2 de outubro, foi aprovado o Decreto Regulamentar $n^{\circ} 16 / 00$, sobre a faturação eletrônica. Em Portugal, para dar o entorno final a essa iniciativa, espera-se o advento da lei sobre o comércio eletrônico. JOSÉ DE OLIVEIRA ASCENSÃO ressalta que: "Em matéria de comércio electrónico, aguardase agora a transposição da Directriz Comunitária n ${ }^{\circ}$ 00/31, de 8 de junho". ${ }^{23}$

Há que se vislumbrar o trabalho realizado nos países da América Latina. Atentese para a participação da Argentina, com a Resolución n ${ }^{\circ}$ 45, datada de 17 de março de 1997, que autoriza a assinatura digital na Administração Pública; a Resolución n 212 / 98, concernente à certificação eletrônica, limitada também ao setor público nacional, e o Decreto Presidencial $n^{\circ} 427 / 98$, que também trata das assinaturas eletrônicas no setor público.

Essa regulamentação serviu de precedente para o surgimento do anteprojeto de lei argentino sobre assinaturas digitais, de 18 de agosto de 1999, que também se estende ao âmbito privado.

No Peru, entrou em vigor em 2000 a Ley n ${ }^{\circ} 27269$, que equipara a validade das assinaturas eletrônicas à da assinatura convencional: trata-se da Ley de Firmas y Certificados Digitales (Lei sobre Assinaturas e Certificados Digitais).

A Colômbia tem se destacado por já possuir uma lei específica sobre o $e$ commerce, a Lei $\mathrm{n}^{\circ}$ 527, que foi baseada na Lei Modelo da UNCITRAL, sancionada e publicada em agosto de 1999.

Deve-se dar destaque também às profundas alterações implementadas pelo México, que introduziu, em 28 de abril de 1999, propostas para modificar os Códigos Comercial e Civil a fim de cobrir transações que utilizariam a assinatura eletrônica, criando em sua própria codificação, através da reforma de artigos e acréscimo de outros, um título chamado Del Comercio Electrónico.

A Ásia está movimentando suas bases legislativas para conceder uma estrutura legal mais sólida às relações comerciais eletrônicas. O Japão já tem uma lei sobre assinaturas digitais e serviços de certificação, decretada em 24 de maio de 2000 . O mesmo pode ser dito sobre a Oceania, que teve na Austrália a promulgação da Lei de Transações Eletrônicas já em 1999. 
Por fim, para dar o fechamento dessa breve análise sobre o panorama legislativo internacional do comércio eletrônico e partir para a observação desse mesmo panorama no Direito brasileiro, é pertinente expor traços da peculiar situação norte-americana.

Os Estados Unidos, devido ao vultoso desenvolvimento na área tecnológica, principalmente no que se refere à informática, possuem a maior gama de leis e projetos de lei relativos ao e-commerce entre os países do globo.

Esse cuidado especial concedido ao comércio eletrônico e sua regulamentação se consubstanciou primordialmente em estudos do próprio governo norte-americano, que se voltaram para uma perspectiva de mundialização do e-commerce. Intitulado $A$ Framework for Global Electronic Commerce (Uma Estrutura para o Comércio Eletrônico Global), esse relatório - publicado pela Casa Branca em $1^{\circ}$ de julho de 1997 - ressalta as diretrizes essenciais acerca do tratamento que deveria ser dado à nova forma de comerciar que aflorava no país.

$\mathrm{Na}$ essência, aponta as mesmas questões dispostas como relevantes pelas organizações internacionais, como a necessidade de se uniformizar as leis comerciais dos países envolvidos no e-commerce, a proteção da propriedade intelectual (copyrights, proteção de bases de dados, patentes, marcas registradas e nomes de domínio), a tutela à privacidade, a segurança nas transações realizadas eletronicamente.

Entre as leis americanas, à guisa de exemplo, pode-se citar o Electronic Communications Privacy Act, Lei Norte-americana sobre Privacidade na Internet; o Electronic Signatures in Global and National Commerce Act, de 8 de junho de 2000, que dispõe sobre assinaturas eletrônicas; o Unsolicited Commercial Electronic Mail Act of 2001, projeto de lei concernente à proibição de mensagens eletrônicas enviadas em massa sem prévia solicitação do destinatário e o Millennium Digital Commerce Act, que tem como princípio a remoção de obstáculos relacionados à obrigatoriedade de um meio "material" para a consecução dos negócios jurídicos, a fim de viabilizar e incentivar as transações eletrônicas.

\subsection{A situação legislativa brasileira em relação ao $e$-commerce}

Em meio a tantas discussões, travadas em um panorama global, está o Brasil. É inegável que, devido ao processo de globalização circundante e a maciça derrubada de fronteiras comerciais, não haveria de escapar à influência do comércio eletrônico. Embora a passos lentos, os legisladores brasileiros trabalham na elaboração de projetos de lei pertinentes ao comércio eletrônico, cujas aprovações estão na iminência de ocorrer.

Entre eles, os mais relevantes são o Projeto de Lei $n^{\circ} 1.483 / 99$, que institui a fatura eletrônica e assinatura digital nas transações de comércio eletrônico, e o Projeto de Lei $n^{\circ} 1.589 / 99$, também conhecido como Projeto da OAB/SP, que dispõe sobre o comércio eletrônico, a validade jurídica do documento eletrônico e a assinatura digital, ambos de iniciativa da Câmara dos Deputados. Os projetos foram apensados devido à similitude da matéria dos dois. 
O Senado Federal também havia elaborado um projeto de lei tendo em vista o comércio eletrônico. Trata-se do Projeto de Lei ${ }^{\circ}$ 672/99, que trata de "qualquer tipo de informação na forma de mensagem de dados usada no contexto de atividades comerciais". ${ }^{24}$ Esse projeto, atendendo ao disposto no caput do art. 65 da Constituição Federal, ${ }^{25}$ após sua aprovação no Senado, foi remetido à Câmara dos Deputados.

Agora sob o $\mathrm{n}^{\circ} 4.906 / 01$, foram anexados a ele os projetos de lei da Câmara dos Deputados supracitados, 1.483/99 e 1.589/99. No decorrer da sua tramitação, ${ }^{26}$ outros dois projetos foram apresentados à Câmara: Projetos de Lei $n^{\circ} \mathrm{s} 6.965 / 02$ e 7.093/02, sendo tais projetos também apensados a ele. O Projeto de Lei $\mathrm{n}^{\circ} 6.965 / 02$, confere valor jurídico à digitalização de documentos, enquanto o Projeto de Lei ${ }^{\circ}$ 7.093/02, dispõe sobre a correspondência eletrônica comercial.

O Projeto de Lei $\mathrm{n}^{\circ} 4.906 / 01$ tramita sob o regime de prioridade, aguardando sua votação no Plenário da Câmara dos Deputados.

Entre outros projetos relacionados à Internet, pode-se mencionar também o Projeto de Lei $\mathrm{n}^{\circ} 3.016 / 00$, relativo à conduta e responsabilidade dos provedores de acesso, apensado ao Projeto de Lei $\mathrm{n}^{\circ} 5.403 / 01$, oriundo do Senado, que trata do acesso às informações da Internet, e o Projeto de Lei ${ }^{\circ} 3.360 / 00$, que trata da privacidade de dados e a relação entre usuários, provedores e portais em redes eletrônicas.

Enquanto tais projetos não são convertidos em lei, o Executivo toma a iniciativa de editar e reeditar medidas provisórias. Para garantir a autenticidade, a integridade e assegurar a validade jurídica dos documentos eletrônicos, foi editada a Medida Provisória $\mathrm{n}^{\circ} 2.200 / 02$, que até setembro de 2001 já estava em sua segunda reedição. Essa medida provisória instituiu a "infra-estrutura de chaves públicas brasileira", ou ICP-Brasil, que é um "conjunto de técnicas, práticas e procedimentos com o objetivo de fornecer suporte à implementação e à operação de um sistema de certificação digital baseado em criptografia de chave pública". ${ }^{27}$

Para melhor elucidar, a criptografia consiste na criação de uma senha e de uma chave para ser decifrada. Na assinatura digital, há uma mistura de dados que necessitam de duas chaves - uma pública e uma privada - para que ela possa ser lida. Por intermédio da criptografia de chave pública, pode-se verificar os requisitos de autenticidade (a autoria da assinatura) e da integridade (correspondendo a seu conteúdo) de modo simples e com um custo relativamente baixo. Com a medida provisória, foi instituída uma "autoridade certificadora" no âmbito estatal.

24 Senado Federal. Portal Legislativo do Senado Federal do Brasil. Disponível em: www.legis.senado.gov.br. Acesso em 10 out. 2002

25 "Art. 65. O projeto de lei aprovado por uma Casa será revisto pela outra, em um só turno de discussão e votação, e enviado à sanção ou promulgação, se a Casa revisora o aprovar, ou arquivado, se o rejeitar."

26 Câmara dos Deputados. E-câmara (Sistema de informações legislativas). Disponível em: www.camara.gov.br/internet/ecamara/default.asp. Acesso em 10 out. 2002.

27 Termo de Referência Comitê Gestor ICP Brasil. Casa Civil da Presidência da República. Disponível em: www.planalto.gov.br. Acesso em 2 set. 2001. 
Ela, consoante o entendimento de ÂNGELA BITTENCOURT BRASIL, "é uma entidade independente e legalmente habilitada para exercer as funções de distribuidor das chaves e pode ser consultado a qualquer tempo, certificando que determinada pessoa é a titular da assinatura digital, da chave pública e da correspectiva chave privada". ${ }^{28}$ No contexto da Medida Provisória ${ }^{\circ}{ }^{2}$.200-2, a autoridade escolhida para o desempenho desse papel foi o Instituto Nacional de Tecnologia da Informação (ITI), que foi por ela transformado em autarquia federal vinculada ao Ministério da Ciência e Tecnologia.

A primeira edição dessa medida provisória suscitou diversas críticas, especialmente por parte da Ordem dos Advogados do Brasil, que apontou algumas conseqüências negativas da criação de um órgão centralizador da emissão de certificação digital. Entre elas, estaria a burocratização do comércio eletrônico, pois a validade da assinatura digital estaria condicionada à chancela de um órgão do Poder Executivo, que deteria o monopólio da certificação dos documentos eletrônicos, onerando excessivamente as atividades comerciais realizadas. Todavia, isso foi sanado nas edições posteriores.

Em sua terceira edição, no art. $10, \S 2^{\circ}$, ressaltou-se que "O disposto nesta medida provisória não obsta a utilização de outro meio de comprovação da autoria e integridade de documentos em forma eletrônica, inclusive os que utilizem certificados não emitidos pela ICP-Brasil, desde que admitido pelas partes como válido ou aceito pela pessoa a quem for oposto o documento". Concedeu-se à iniciativa privada, logo, a possibilidade de também atuar como autoridade certificadora de documentos eletrônicos.

Com isso, pode-se inferir também que há uma tendência no Brasil de se acompanhar a corrente mundial, liderada pelos Estados Unidos e pela União Européia, de equiparação do documento eletrônico ao documento convencional, no que se refere à questão probatória.

O Projeto de Lei $n^{\circ} 1.483 / 99$ (apensado ao Projeto de Lei ${ }^{\circ} 1.589 / 99$ ) trabalha bastante com os temas da certificação, da assinatura digital e da documentação eletrônica. Ele sofreu um substitutivo, que é uma nova redação da lei visando a uma consolidação, elaborado por uma comissão especial da Câmara dos Deputados, tendo como relator o Deputado JÚLIO SEMEGHINI. Após isso, como exposto supra, esse projeto foi apensado ao Projeto de Lei $n^{\circ} 4.906 / 01$, que "dispõe sobre a validade jurídica e o valor probante do documento eletrônico e da assinatura digital, regula a certificação digital, institui normas para as transações de comércio eletrônico e dá outras providências".

Em linhas gerais, quanto aos efeitos jurídicos do documento eletrônico, optouse por seguir o que preceitua a Lei Modelo da UNCITRAL. Para a validação da assinatura digital, foi acolhido o sistema de criptografia assimétrica (ou de chave pública, o mesmo sistema da ICP-Brasil), mas com a ressalva de que, se porventura vierem a existir outros métodos igualmente eficazes para satisfazer seus requisitos de validade, tais sistemas possam vir a ser também utilizados.

28 BRASIL, Angela Bittencourt. Assinatura digital não é assinatura formal. Ciberlex. Disponível em: www.ciberlex.adv.br. Acesso em 14 jul. 2001. 
O substitutivo de SEMEGHINI ressalta a importância de haver uma certificação para que se possa atribuir validade aos documentos eletrônicos com assinatura digital e, conforme já prenunciou a Medida Provisória $n^{\circ} 2.200 / 02$, estabeleceu que tanto entidades públicas como privadas podem atuar como autoridades certificadoras, independentemente de autorização estatal.

Dada a relevância da matéria, procurou-se uma atenção especial no que tange especificamente ao comércio eletrônico. Preliminarmente, tratou-se da contratação eletrônica. Nela, foi trabalhado um novo conceito de contrato, o qual não está abarcado na codificação civil devido às suas peculiaridades, que advêm da troca de documentos eletrônicos emanados da manifestação de vontade das partes envolvidas na transação comercial.

Foi estabelecido, no texto do substitutivo, que essa manifestação de vontades tornar-se-ia perfeita no momento em que o documento eletrônico é transmitido para o endereço eletrônico definido por acordo das partes e nele for recebido. Quanto às faturas e duplicatas eletrônicas, elas foram equiparadas às convencionais. Optou-se também pela manutenção da eficácia do Código de Defesa do Consumidor, adaptando-se seus princípios à realidade do comércio eletrônico.

O projeto de lei, consentâneo com a visão mundial sobre o tema, salientou a relevância da proteção da privacidade do consumidor, disciplinando o modo com que os dados pessoais devem ser utilizados, primando pela manutenção do sigilo desses como regra geral.

Assim, o estabelecimento comercial só poderá solicitar as informações de caráter privado sobre o consumidor que forem necessárias à efetivação do negócio que está ofertando. Com isso, obriga-se o comerciante a resguardar essas informações a não ser que o consumidor o autorize, de modo prévio e expresso, a divulgá-las ou cedê-las a terceiros.

Por fim, no Projeto de Lei n ${ }^{\circ} 4.906 / 01$, houve a inclusão, no capítulo referente ao comércio eletrônico, das responsabilidades e obrigações dos provedores, sejam eles provedores de acesso, conteúdo, conexão e transmissão de informações e tratamento de dados, disciplina de suas obrigações e isenções de responsabilidade sobre o conteúdo veiculado, oriundas da natureza de sua atividade.

Como exemplo de obrigações, pode-se citar a obrigação de não tomar conhecimento sobre as informações contidas nos documentos eletrônicos trocados por seu intermédio, e, como eventuais isenções, cabe mencionar aquelas que desobrigam o provedor de fiscalizar o conteúdo das informações transmitidas.

É importante também destacar que o projeto de lei brasileiro sobre comércio eletrônico explicita as sanções penais, tornando os tipos penais equivalentes aos que já existem na legislação penal em vigor.

Quanto à defesa da propriedade intelectual no meio eletrônico, a sua disciplina jurídica permanece a mesma utilizada para a tutela dos direitos autorais nos demais meios, através da Lei do Direito Autoral (9.610/98). Dessa feita, embora essa lei seja 
bastante abrangente para os direitos autorais em geral, percebe-se uma lacuna na legislação brasileira quanto à proteção dos direitos autorais que porventura sejam violados no comércio eletrônico, devido à própria facilidade de reprodução que o meio eletrônico propicia.

São muito comuns as controvérsias judiciais oriundas de casos de publicação de artigos na Internet sem a prévia autorização do autor, cópias indiscriminadas do layout de sites da Web ou disseminação de gravações de músicas, especialmente sob o formato de MP3, sem o consentimento das gravadoras às quais os cantores e intérpretes estão vinculados.

Em relação ao tratamento tributário do comércio eletrônico não há lei ou projeto de lei específico. A questão mais debatida é sobre a incidência do ISS (Imposto sobre Serviços) e do ICMS (Imposto sobre Circulação de Mercadorias e Serviços) nas operações comerciais ocorridas na Internet.

Recentemente, o STJ, em decisão de sua Primeira Turma, decidiu que os provedores que comercializam o acesso à Internet devem recolher o ICMS, ficando isentos da cobrança os provedores de acesso gratuito: "O relator do processo, o Ministro JOSÉ DELGADO, acolheu o recurso do Estado do Paraná, autorizando a cobrança do imposto à Sercomtel, argumentando que a relação entre o prestador de serviço (provedor) e o usuário é de natureza negocial visando a possibilitar a comunicação desejada". ${ }^{29}$ Como se evidencia, no âmbito tributário brasileiro ainda há muitos aspectos a serem debatidos, antes de se assentar um entendimento pacífico sobre a tributação no $e$ commerce.

Além desses pontos principais, que são os mais polêmicos, há que se considerar que, como o comércio eletrônico brasileiro está em franca expansão, diversas questões incidentais emergem, necessitando de um estudo apurado por parte dos juristas e legisladores das situações que devem ser passíveis de nova regulamentação e das que já estão abarcadas na legislação em vigor.

\section{A CONTRATAÇÃO ELETRÔNICA}

\subsection{Noções sobre contrato eletrônico}

O contrato eletrônico tem uma perspectiva diferenciada em determinados aspectos, como a determinação do momento e do lugar da formação, o que faz com que haja necessidade de uma classificação que transcenda os moldes civilistas de direito interno. Assim, é relevante o estudo também sob a perspectiva dos contratos internacionais, haja vista a superação dos conceitos de tempo-espaço suscitados pelo meio virtual, como será delineado no presente trabalho, a posteriori.

29 LÔBO, Cristiana. Provedores pagos devem recolher ICMS, diz STJ. Homepage IG. Disponível em: www.ig.com.br/home/editorial/stories/editorial_body. Acesso em 9 set. 2001. 
Inicialmente, é necessário apresentar as definições de contrato eletrônico. NEWTON DE LUCCA discorre sobre essa questão, afirmando que não implicaria a formação de um novo tipo de contrato no âmbito da teoria geral dos contratos, pois o contrato permaneceria sempre um contrato de compra e venda, de prestação de serviço ou de locação de coisa, mas celebrado por um meio eletrônico. ${ }^{30}$

Dessa maneira, pode-se encontrar, entre os contratos eletrônicos, vários tipos de contrato, sejam típicos - previstos nos textos normativos e que devem seguir os moldes pré-estabelecidos em lei -, sejam atípicos, que permitem maior margem de criação das partes contratantes, as quais devem se atentar para os princípios gerais dos contratos.

Exemplo de como um contrato típico pode ser efetuado pelo meio eletrônico, mencionado por PAULA FORGIONI, é o da compra e venda mercantil, que está disciplinada no art. 191 do Código Comercial. Uma parte pode enviar um e-mail à outra, contendo proposta especificando a coisa, o preço e as condições - que são os elementos essenciais da compra e venda mercantil -, e o destinatário, por sua vez, pode expedir outro, declarando sua aceitação aos termos da proposta. Com isso, pode-se reputar concluída a compra e venda mercantil.

Outro modo de conclusão de uma compra e venda mercantil no meio virtual se refere aos sites em que as empresas oferecem produtos aos consumidores. Se a página da Internet oferece os elementos essenciais para que seja celebrado o negócio, o art. 191 do Código Comercial incide no instante em que o adquirente clica na tecla "comprar". ${ }^{31}$

No entender de FÁBIO ULHOA COELHO, o contrato eletrônico tem como nota característica o fato de ser celebrado por meio de transmissão eletrônica de dados. "A manifestação de vontade dos contratantes (oferta e aceitação) não se veicula nem oralmente, nem por documento escrito, mas pelo registro em meio virtual". ${ }^{32}$ SEMY GLANZ assevera que o contrato eletrônico é aquele celebrado por meio de programas de computador ou aparelhos com tais programas, dispensando assinatura, ou exigindo assinatura codificada ou senha. ${ }^{33}$

OLIVER ITEANU, citado por GLANZ, propõe duas definições para o contrato eletrônico. Na primeira, é "convenção pela qual uma oferta e uma aceitação se encontram

30 LUCCA, Newton de. Títulos e contratos eletrônicos: o advento da informática e o seu impacto no mundo jurídico. In: Direito e Internet - aspectos jurídicos relevantes. Bauru, São Paulo: EDIPRO, 2000 , p. 46

31 FORGIONI, Paula A. Apontamentos sobre aspectos jurídicos do e-commerce. In: Revista de direito mercantil, industrial, econômico e financeiro, ano XXXIX (nova série), São Paulo: Malheiros, p. 70, jul./set. 2000.

32 COELHO, Fábio Ulhoa. O contrato eletrônico: conceito e prova. Disponível em: www.ulhoacoelho.adv.br. Acesso em 20 maio 2002.

33 GLANZ, Semy. Internet e contrato eletrônico. In: Revista dos Tribunais, n. 757, São Paulo: Revista dos Tribunais, 1998, p. 72. 
numa rede internacional de telecomunicações" e na segunda, mais analítica, "o contrato de comércio eletrônico pode definir-se como o encontro de uma oferta de bens ou serviços que se exprime de modo audiovisual através de uma rede internacional de telecomunicações e de uma aceitação suscetível de manifestar-se por meio da interatividade". ${ }^{34}$

\subsection{Espécies de contrato eletrônico}

Os contratos eletrônicos possuem certas peculiaridades em relação aos contratos convencionais. Eles podem ter duas modalidades de objeto, sendo a primeira uma prestação efetuada através do próprio meio eletrônico, como o fornecimento de um software, ou de uma música, cujo download implica o próprio cumprimento dessa prestação.

É possível citar também os serviços de informações, de bancos de dados, de mensagens eletrônicas, todos eles prestados através da multimídia.

A segunda, mais comum, realiza-se principalmente com a compra e venda ou prestação de serviços que, embora se engendrem no meio virtual, dependem de um meio diferente, externo a ele, para a entrega ou execução. Diversos produtos e serviços podem ser ofertados através do meio virtual, entre eles serviços bancários, seguros de variadas espécies, jogos e apostas em loterias, fornecimento de notícias, assinaturas de jornais, fornecimento de programas gratuitos, entre outros.

Os bancos oferecem os chamados serviços de home banking que, por intermédio da comunicação entre computadores, permitem ao cliente o acesso a diversos serviços, prescindindo da necessidade de ele ir fisicamente ao banco para consulta de saldos, obtenção de extratos, transferência de valores entre contas, abertura de contas, aplicações e pagamentos através do $e$-cash, o "dinheiro eletrônico".

O papel das instituições bancárias no que se refere à contratação eletrônica é fundamental. Como se sabe, a extinção do vínculo contratual se dá de modo satisfatório com o adimplemento da prestação. Nada mais natural que, nos contratos formados no meio virtual, o pagamento se dê também de modo eletrônico.

O pagamento através do e-cash pode se dar de duas formas. Na primeira, que utiliza os serviços bancários tradicionais para realizar as transferências de fundos, a instituição financeira - ou a operadora de cartão de crédito - funciona como um intermediário entre o consumidor e o fornecedor do produto ou serviço, fazendo com que o valor monetário seja diretamente transferido do computador do usuário para a instituição.

O processo ocorre do seguinte modo: o comerciante ou o comprador informam o valor a ser pago, o número do cartão do comprador e o da conta do favorecido, ocorrendo aí a transferência, mediante a ação da operadora do cartão. 
O e-cash também pode se dar através da transferência direta para o computador do credor da transação. Nesse caso, os recursos financeiros ficam armazenados no computador do usuário em forma de dados digitais.

Tal como as operações bancárias, as operações de compra e venda são intensamente difundidas no meio virtual. O procedimento de compra e venda pela Internet inicia-se com a oferta, que se consubstancia com a colocação da mercadoria na tela do computador.

Para se caracterizar como oferta, deve ter apresentada a imagem da mercadoria, suas características técnicas, seu preço e as condições pertinentes ao pagamento e à entrega. Ao examinar essas características, o comprador, observando que elas vão ao encontro de suas expectativas, manifesta sua intenção de comprar. Essa aceitação normalmente ocorre através de uma comunicação por intermédio de via eletrônica, ou pelo pagamento.

Um exemplo marcante de compra e venda através da Internet é a de veículos automotores. Existem sites que apenas informam os consumidores sobre as características dos veículos, bem como os preços e a quantidade disponível em estoque, sem que haja formalização on-line da compra.

Esses casos são muito assemelhados à publicidade em jornais, revistas, cabendo ao consumidor a iniciativa de compra.

Há, porém, sites que possibilitam ao consumidor a opção por determinado veículo dotado das características que mais lhe agradam, recolhendo os pedidos de compra online e repassando aos concessionários conveniados.

Com isso, o consumidor, além de poder localizar o automóvel com as exatas características que deseja, não é mais obrigado a se contentar com os veículos disponíveis no concessionário de seu domicílio, além de lhe proporcionar acesso aos melhores preços praticados pelas concessionárias de todo o país. ${ }^{35}$

Profissionais liberais têm se valido da Internet para a prestação de serviços online, através de consultas. Uma vasta quantidade de empresas seguradoras tem apresentado seus planos de seguro, e muitos sites estão abertos à possibilidade de o usuário realizar a proposta de contratação de seguro no próprio meio virtual.

Há a possibilidade também de se efetuarem negócios on-line em sites de corretoras de títulos e valores mobiliários, com aplicações em ações da Bolsa de Valores. Muitas empresas estão ofertando a prestação de serviços educacionais pela Internet, como a realização de cursos on-line. Com os exemplos acima, pode-se observar a grande gama de opções de negócios que são formalizados através de contratos eletrônicos e inferir as proporções que o comércio eletrônico vem tomando na realidade.

35 LINHARES, Marcel Queiroz. Venda de veículos novos através da Internet: reflexos no campo da exclusividade inerente à concessão de veículos automotores. In: Revista de direito mercantil, industrial, econômico e financeiro, ano XL (nova série), São Paulo: Malheiros, p. 115-116, jan./mar. 2001. 


\subsection{Os contratos eletrônicos como contratos internacionais}

No direito comercial internacional, devido à própria dinâmica das relações comerciais do mundo moderno, os contratos seguem um novo modelo de formação, em que a classificação dicotômica dos contratos como "entre presentes" e "entre ausentes" se encontra superada pelo desenvolvimento das telecomunicações.

Em muitas ocasiões, percebe-se que o contrato eletrônico transcende o direito interno, por conter algum elemento que o caracteriza como contrato internacional, como partes oriundas de países de nacionalidades diferentes, ou local de fabricação e entrega do objeto da prestação situados em uma nação distinta daquela em que está situado o proponente ou o aceitante do contrato. MARISTELA BASSO ${ }^{36}$ apresenta uma classificação consentânea com essa nova realidade, com três espécies de formação de contratos.

Há os contratos de formação instantânea, em que não há intervalo considerável entre a oferta e a aceitação. Neles, o contrato é feito por comunicação direta, concluído com as partes frente a frente, ou indireta, através de contato simultâneo, por intermédio da telecomunicação.

A comunicação direta seria a manifestação da vontade expressa de viva voz, oral, entre presentes, ou transmitida através de impulsos telefônicos. O momento em que o contrato se forma é coincidente com aquele em que o oblato aceita a oferta, comunicação esta que deve ser inteligível ao proponente para ser válida.

A comunicação indireta coincide com os avanços da telemática, que subverteu a noção de tempo real. "Um computador conectado a uma rede de telecomunicações adequada permite ao comerciante realizar transações comerciais antes mesmo da formalização dos dados contratuais, permitindo-lhe apresentar propostas, assim como aceitar outras, com mais rapidez e eficiência que o correio tradicional ou outros sistemas, como prospectos, catálogos e circulares". ${ }^{37}$

Exemplos de meios de comunicação indireta são aqueles que se valem do sinal eletrônico para conduzir a mensagem para o destinatário, como as contratações por videoconferência, telex, telefax e, sobretudo, o computador.

Segundo BASSO, as regras elaboradas pela doutrina clássica para formação de contratos entre partes "não fisicamente presentes" podem ser transpostas aos contratos negociados por meios eletrônicos, não constituindo esses, logo, empecilho aos princípios clássicos de formação dos contratos, residindo o problema apenas na determinação do momento e do lugar de sua formação, além dos meios de autenticação (prova).

"É preciso, portanto, que enfrentemos as questões que na prática comercial internacional são freqüentes, tais como: quando se conclui um contrato negociado através

36 BASSO, Maristela. Contratos internacionais do comércio: negociação, conclusão, prática. Porto Alegre: Livraria do Advogado, 1994, p. 77.

37 Idem, ibidem, p. 80. 
dos meios eletrônicos? Qual o lugar de sua conclusão? Em caso de perda ou alteração de uma mensagem, durante sua transmissão, quem é o responsável? Podemos responsabilizar um contratante por uma mensagem enviada por pessoa não autorizada?"38

A conclusão dos contratos por via eletrônica ocorre de modo instantâneo quando os contratantes, em seus respectivos terminais receptores, propõem e aceitam as cláusulas contratuais simultaneamente, havendo apenas entre a oferta e a aceitação o intervalo necessário para a propagação do sinal eletrônico que conduz a informação que contém a manifestação da vontade.

Nessa espécie de contratação, deve-se assegurar a qualidade das mensagens transmitidas, bem como a identidade dos contratantes. A prova da formação desses contratos pode ser feita através do registro dessas transmissões.

Há também os contratos de formação ex intervallo, quando ocorre um intervalo considerável entre a oferta e a aceitação. Nessa espécie contratual, a aceitação não é imediata à oferta, ocorrendo um intervalo de tempo entre as manifestações de vontade. Tais contratos podem ser formados mediante comunicação direta - com as partes frente a frente, ou contratando por telefone; comunicação indireta através de correspondência epistolar - troca de cartas, telegramas, e mediante comunicação indireta através da telemática.

Por fim, há os contratos de formação ex intervallo temporis, de formação sucessiva ou progressiva, em que o intervalo de tempo comporta uma série de negociações: as partes vão trocando propostas, até que a oferta de uma é aceita pela outra, em um "processo sedimentar".

Quanto à determinação do momento em que se forma o contrato eletrônico, discute-se qual a técnica a ser utilizada: a da extensão da ficção legal conferida aos contratos realizados por telefone, considerando-os realizados entre presentes, ou a que pressupõe ser o contrato eletrônico uma modalidade de contratação entre ausentes, devido à constatação fática de que as partes não se encontram fisicamente presentes durante a contratação.

GUILHERME MAGALHÃES MARTINS tem esse entendimento, asseverando que o computador ligado à Internet se presta à comunicação de vontades já aperfeiçoadas, bem como a auxiliar no processo de formação da vontade, através da oferta permanente contida em um site. ${ }^{39}$

Além disso, ele entende que as características fundamentais do contrato eletrônico se referem ao meio da oferta, formulada através de uma rede internacional de telecomunicações, de modo audiovisual, e à interatividade entre profissional e cliente, cuja aceitação se expressaria pelo mesmo meio, seja em tempo real, seja por intermédio do correio eletrônico. 
Outro ponto bastante peculiar no que diz respeito aos contratos eletrônicos é a definição do local em que eles se reputam formados, tendo grande importância no direito interno e internacional, haja vista a necessidade de apurar o foro competente e determinar a legislação aplicável.

Disciplina o art. 435 do Código Civil de 2002, do direito interno brasileiro, que "reputar-se-á celebrado o contrato no lugar em que foi proposto". Assim, se a transação virtual ocorre entre dois sujeitos, estando fisicamente o proponente em Goiás e o aceitante na Paraíba, Goiás é considerado como o local da conclusão do contrato.

Agora, no que se refere a partes que residem em locais diferentes, o ordenamento jurídico brasileiro, no art. $9^{\circ}$ da Lei de Introdução ao Código Civil, disciplina que a "obrigação resultante do contrato reputa-se constituída no lugar em que residir o proponente".

Suponha-se que seja o proponente domiciliado na Itália, mas que no momento da contratação esteja conectado em um computador na França - onde está residindo no momento, e este negocie com um brasileiro que está no Rio Grande do Sul. No caso, a França é considerada como o local em que se constituiu a obrigação.

O local da residência indica a lei do local da proposta, não se adotando o critério domiciliar devido à mobilidade das relações negociais, pois freqüentemente se percebe que a efetivação dos negócios internacionais se dá fora do domicílio dos contratantes algo que ocorre, sobretudo, nos contratos eletrônicos.

Considerando-se que haja contratos virtuais entre presentes, dependem estes da lei do lugar onde foram contraídos, não importando a nacionalidade, domicílio ou residência dos contratantes.

Normalmente, os contratos por correspondência - aos quais muitos autores têm disposto como análogos aos contratos efetuados através de e-mail - têm indicado o local da celebração do contrato e o proponente, fazendo com que se reputem constituídos no lugar em que ele residir, sendo a lei desse local a aplicável para reger as obrigações contratuais.

\subsection{Contratos eletrônicos e o Código de Defesa do Consumidor}

Um tema de grande evidência é a relação do comércio eletrônico brasileiro com os direitos dos consumidores. Nesse particular, há a aplicabilidade integral do Código de Defesa do Consumidor (Lei $\mathrm{n}^{\circ}$ 8.078/90) e seus princípios, que é reiterada pelo Projeto de Lei $n^{\circ} 4.906 / 01$.

Por exemplo, permanece o dever de informação ao consumidor, consoante o disposto no art. 30 do CDC, em que a oferta deve ser clara e precisa. Como os contratos engendrados no meio virtual são precipuamente contratos à distância, eles devem ter suas condições gerais dispostas de modo a transparecer, para o consumidor, completo conhecimento sobre o produto que irá adquirir, estando essas cláusulas claras e compreensíveis, fazendo valer outro princípio inerente às normas protetivas do consumidor, que é o da transparência. 
O dever de informação garante o equilíbrio entre as partes contratantes e consiste em um conjunto de elementos relacionados à relação jurídica, à coisa envolvida na prestação, ou a atividades suscetíveis de causar danos a terceiros, ou a um dos contratantes.

Ele pressupõe um nível de conhecimento relativo ao nível educacional do leigo, envolvendo dados relevantes capazes de alterar a base do negócio, no sentido de que, ao conhecê-lo, não se contrataria ou o faria em outras condições. ${ }^{40}$

Assim, à guisa de exemplo, imagine-se que esteja colocado à venda determinado aparelho eletrodoméstico em um portal de compras pela Internet. A oferta do produto, cuja finalidade é exatamente a de induzir a contratar por intermédio de propaganda, realçava suas qualidades.

Entretanto, omitiu-se no site a informação de que o aparelho só se encontra disponível para a voltagem de $110 \mathrm{~V}$. Suponha-se que um consumidor residente em Santa Catarina, onde a voltagem padrão é de $220 \mathrm{~V}$, tenha adquirido o produto para uso próprio em sua residência, sem saber daquele dado.

Evidentemente, o eletrodoméstico seria fatalmente inutilizado se exposto à voltagem da cidade do consumidor, ou ficaria sem utilidade prática, no caso de nãoexposição. Trata-se de uma informação técnica que deveria ser fornecida no site, pois, se soubesse desse dado, certamente o consumidor não teria adquirido o produto.

Outro artigo do Código de Defesa do Consumidor que tem grande pertinência no comércio eletrônico é o art. 49, que trata dos casos de venda de produtos fora do estabelecimento comercial, ou seja, de venda à distância - característica basilar das relações de consumo por meio da Internet.

Consoante o caput do artigo, "O consumidor pode desistir do contrato, no prazo de 7 (sete) dias a contar de sua assinatura ou do ato de recebimento do produto ou serviço sempre que a contratação de fornecimento de produtos e serviços ocorrer fora do estabelecimento comercial, especialmente por telefone ou a domicílio".

Ressalte-se que a enumeração "por telefone e a domicílio" é numerus apertus, logo, exemplificativa, sendo esse caráter dado pelo advérbio "especialmente".

Assim sendo, da própria leitura desse artigo se evidencia a aplicabilidade do CDC nas circunstâncias em que o consumidor, após adquirir determinado bem através de uma operação de comércio eletrônico efetuada pela Internet (ou seja, fora do estabelecimento comercial, haja vista as "empresas virtuais" devam estar estabelecidas legalmente com endereço próprio no mundo real, como qualquer outra empresa deve sê-lo), decide por uma devolução do produto.

Esse direito de arrependimento é resguardado pela razão de que o consumidor, ao realizar a operação de compra por intermédio da Internet, encontra-se em um estado de vulnerabilidade em relação àquele que tem a possibilidade de se dirigir a um estabelecimento comercial e observar de perto as características do produto ofertado. 
Pode-se exemplificar o exercício do direito de arrependimento com a compra de livro através de uma livraria virtual. Nas livrarias constituídas fisicamente, os consumidores podem folhear as páginas, ler rapidamente trechos das obras e, por fim, optar por adquirir determinado exemplar.

Contudo, em um site da Web, o consumidor só tem acesso à reprodução da capa do livro e, em alguns casos, a uma sinopse bastante simples. A probabilidade de o consumidor se equivocar e adquirir um produto aquém das suas expectativas é muito alta. Logo, o prazo de sete dias para arrependimento é essencial para mitigar essa situação.

FÁBIO ULHOA COELHO ${ }^{41}$ tem entendimento distinto da maior parte da doutrina acerca da aplicabilidade do art. 49 do CDC ao comércio eletrônico. No entender do autor, tal artigo não deve ser aplicado, porque o negócio seria concretizado dentro do estabelecimento do empresário, por se constituir estabelecimento virtual.

Aponta o estabelecimento virtual como uma das inovações trazidas pelo comércio eletrônico: fisicamente inacessível, é acessado por via de transmissão eletrônica de dados, sendo identificado pelo "nome de domínio", que tem como uma de suas funções a de identificar o "lugar" em que o consumidor pode comprar o produto ou serviço, bem como a de realizar a conexão entre emissor e destinatário das informações veiculadas pela rede: é o endereço eletrônico que permite o acesso ao estabelecimento virtual.

Devido a essa função de identificação, o registro do nome de domínio, realizado pela FAPESP (Fundação de Amparo à Pesquisa do Estado de São Paulo), não pode ter seu núcleo coincidente com expressão protegida como marca (que é registrada pelo INPI) por outro empresário. Além disso, o registro do nome de domínio possui apenas natureza declaratória, ao contrário do caráter constitutivo do registro de marca no INPI.

Segundo COELHO, a diferenciação entre o estabelecimento físico do virtual é pelo meio de deslocamento: se for feito no espaço, é físico. Entre os dois tipos de estabelecimento há aspectos comuns, como o fundo de empresa (valor agregado ao conjunto de bens que o compõe).

$\mathrm{O}$ valor do estabelecimento virtual dependeria de fatores como a quantidade significativa de visitantes, o volume de transações, layout da página estruturado e atraente, sistemas de segurança de transmissão de dados confiáveis. JOSÉ OLINTO DE TOLEDO RIDOLFO, no mesmo sentido, ressalta que: "Se, de alguma forma, a clientela compunha, no passado, um dos elementos constitutivos do corpo etéreo do que conhecemos por fundo de comércio, com o advento da Internet, a clientela, nesse caso, o usuário ou internauta, ganhou a dimensão de ativo imaterial" ${ }^{42}$ Assim, no meio 
virtual, o valor da empresa aumenta substancialmente à medida que há uma grande gama de consumidores que se dispõem a adquirir seus produtos e serviços.

ULHOA COELHO coloca os portais como exemplos de estabelecimentos virtuais que são negociados por preço que reflete o potencial de retorno financeiro do investimento, não o valor dos bens componentes. Ele ressalta também que:

“(...) o comércio eletrônico não torna obsoleto o conceito de estabelecimento: também o empresário que deseja operar exclusivamente no ambiente virtual reúne bens tangíveis e intangíveis indispensáveis à exploração econômica. A livraria eletrônica deve ter livros em estoque, equipamentos próprios à transmissão e recepção de dados e imagens, marca, know-how, etc. A imaterialidade ínsita ao estabelecimento virtual não se refere aos bens componentes (que são materiais ou não, como em qualquer estabelecimento), mas à acessibilidade." ${ }^{\prime 3}$

Por fim, um detalhe a ser observado é que o contrato eletrônico via de regra tem as características típicas de contrato de adesão, com as mesmas conseqüências jurídicas que advêm desse fato nas contratações convencionais, como a presunção de boa-fé e a noção de hipossuficiência do consumidor, que levam à interpretação mais favorável para aquele que aderiu ao contrato.

\subsection{Prova da contratação eletrônica}

A característica mais marcante dos contratos eletrônicos é a imaterialidade. Eles não estão apostos sobre um suporte palpável, como o papel, mas se consubstanciam através de seqüência de informações digitais, dados luminosos etéreos que são facilmente suscetíveis de adulterações.

Cabe reiterar que, no Direito brasileiro, vigora o princípio da liberdade de forma: a forma eletrônica é válida, salvo se houver disposição de lei em contrário.

Portanto, não se pode negar a existência e a validade de um contrato eletrônico. Todavia, a comprovação em juízo do ato praticado se torna extremamente complexa.

Embora seja "imaterial", tendo menores formalidades do que o contrato escrito, a conceituação doutrinária define documento como uma representação exterior do fato a ser provado.

Logo, é pacífico que o contrato eletrônico está inserido no conceito de documento, conforme leciona CHIOVENDA: "è ogni rappresentazione materiale destinata ed idonea a riprodure una data manifestazione del pensiero". ${ }^{44}$

43 COELHO, Fábio Ulhoa. Curso de direito comercial. São Paulo: Saraiva, v. 3, 2000, p. 34.

44 "(...) é toda representação material destinada e idônea a reproduzir uma manifestação do pensamento." CHIOVENDA apud BRUNO, Marcos Gomes da Silva. Valor jurídico dos contratos eletrônicos. Revista Bonijuris, ano XIII, n. 457, p. 13, dez. 2001. 
A prova escrita prevalece sobre as demais devido à facilidade de se produzir prova acerca da existência do negócio, como a existência de assinatura, que serve para admitir a presunção da autoria do documento e do conhecimento do conteúdo pelo seu signatário.

Muitas questões são debatidas sobre o reconhecimento da integridade do conteúdo do documento, devido à possibilidade de haver alterações. A identidade das partes contratantes, aberta a falsidades ideológicas e a contratação por parte de incapazes, assim como a falta de assinatura de próprio punho, também são apontadas por MARCOS GOMES DA SILVA BRUNO como problemas envolvendo os contratos eletrônicos.

Ele ainda conclui que a plenitude do contrato eletrônico depende da capacidade de mantê-lo íntegro e não deteriorável, vez que sendo um suporte sujeito a adulterações imperceptíveis, perde parte de sua confiabilidade. ${ }^{45}$

Para que se prove que um contrato eletrônico não está eivado de máculas, as operações a serem realizadas devem ser condizentes com o próprio meio imaterial em que ele é formado. Por isso, termos como criptografia, certificação eletrônica e assinatura digital estão se tornando cada vez mais recorrentes no vocabulário jurídico da atualidade.

A criptografia se configura com a transformação de uma mensagem em uma forma ininteligível, com a utilização de algoritmos e funções matemáticas codificadoras.

A mensagem transmitida através da criptografia só será lida se o destinatário possuir a chave que recompõe a estrutura inicial da mensagem.

A codificação pode ser feita com apenas um código, utilizado tanto para criptografar como para descriptografar o texto: essa forma, contudo, não oferece muita segurança, pois nesse caso o sigilo se compromete pelo fato de tanto o remetente como o destinatário possuírem conhecimento da chave; além disso, não possibilita uma perfeita identificação das partes, pois não se pode ter certeza sobre quem é o destinatário e quem é o receptor.

Para se obter maior segurança no processo de encriptação, utiliza-se com freqüência de duas chaves distintas, sendo a primeira de conhecimento apenas do remetente, servindo para transmissão da mensagem, e a segunda, de conhecimento exclusivo do destinatário, prestando-se à decodificação.

O jornal Folha de São Paulo de 4 de dezembro de 2000, em reportagem acerca da legislação sobre o comércio eletrônico no Brasil, explicou em um quadro da Editoria de Arte como funcionam a assinatura e o certificado eletrônico. O processo será descrito sucintamente nas linhas a seguir.

"A princípio, o usuário 1 - proponente - envia um contrato para o usuário 2 - aceitante - para que este também assine e deposite a quantia acertada. A 
assinatura do contrato deve ser certificada por uma entidade previamente credenciada. Toda transação será feita pela Internet.

O usuário 1 cria, por intermédio de um programa, uma chave pública e uma chave privada em seu computador. A chave privada permanece na memória do computador, e ele só tem acesso a ela por meio de uma senha. A chave pública o usuário 1 envia à entidade certificadora. Ambas as chaves são criadas simultaneamente, e uma afere a autenticidade da outra.

A entidade certificadora mantém arquivada a chave pública do usuário 1 , que também pode mandá-la para outros interlocutores comerciais.

$\mathrm{O}$ usuário 1 redige o contrato em seu computador, nos moldes de um contrato comum em papel, mas o "assina" com sua chave privada. Nesse ponto, podem ocorrer dois procedimentos:

a) o usuário 1 envia o contrato com sua chave privada para a entidade certificadora. A entidade confronta essa chave com a chave pública em seu poder. Se ambas se aceitam mutuamente, como uma chave comum e seu molde original, a entidade emite um certificado, atestando que aquela assinatura é de fato daquele usuário, coloca nesse certificado sua própria assinatura pública, e devolve o contrato ao usuário 1;

b) o contrato vai do usuário 1 para a entidade certificadora, que adota os demais procedimentos acima, mas já envia direto o contrato certificado para o usuário 2. Se a chave privada e a pública não "baterem", o certificado não é emitido.

O usuário 2 recebe o contrato - diretamente do usuário 1 ou da entidade certificadora - e checa o certificado. Ele pode, como mais uma atitude de proteção, pedir à entidade certificadora que ateste a veracidade de sua chave pública, ou seja, se foi ela mesma que emitiu aquele certificado.

O usuário 2 assina o contrato com sua chave privada e o procedimento anterior se repete. $\mathrm{O}$ contrato certificado fica arquivado no computador dos usuários 1 e 2 e nos arquivos da entidade certificadora. Pode ser impresso a qualquer momento." 46

O sistema de chaves públicas e privadas tem como vantagem a possibilidade de identificação do remetente e do receptor, já que a chave privada é de conhecimento exclusivo do remetente, enquanto o destinatário deve conhecer a chave pública, correspondente à chave privada do remetente, que é a única capaz de decodificá-la.

Esse sistema é conhecido por “criptografia assimétrica”. É essa chave privadaa assinatura digital do remetente - que será colocada nos contratos por ele propostos a fim de imprimir autenticidade ao documento eletrônico. 
O procedimento de utilização de uma assinatura eletrônica, como foi delineado supra, envolve sua criação e verificação. A verificação da assinatura eletrônica envolve a constatação de que ela foi criada com a utilização da chave privada e de que a mensagem não foi alterada em seu conteúdo.

PAULA FORGIONI ressalta que "a probabilidade de um mau funcionamento ou falha de segurança na assinatura digital criptografada é extremamente remota e sempre inferior ao risco de falsificação de uma assinatura tradicional ou de um documento escrito". ${ }^{47}$

A certificação eletrônica consiste na confirmação da associação entre uma pessoa e uma chave pública. Trata-se de um sistema que certifica a ligação entre a dupla de chaves e uma pessoa identificada, imprimindo segurança à contratação efetuada por meio eletrônico. A autoridade certificadora, uma vez confirmada essa ligação, emite certificados, atestando a validade da assinatura digital.

A segurança de homepages que oferecem operações de alto risco potencial quando realizadas via Internet (como é o caso das operações bancárias ou contratação de seguros) e a codificação de números de cartões de crédito também são obtidas por intermédio de métodos criptográficos.

Há uma tendência jurisprudencial de aceitação da senha pessoal como um equivalente da assinatura de próprio punho, reconhecendo o ato como sendo praticado por determinada pessoa. Já quanto à assinatura eletrônica, há iniciativas legislativas e uma medida provisória em vigor, cujos detalhes foram esmiuçados no capítulo pertinente aos projetos de lei brasileiros.

\section{CONCLUSÃO}

Por intermédio da pesquisa realizada, objetivou-se retratar um panorama genérico acerca do comércio eletrônico e suas ligações com o Direito. Nas considerações iniciais, relativas ao capítulo das diretrizes gerais sobre comércio eletrônico, foram esmiuçados, em três tópicos: conceito de comércio eletrônico, notas preliminares sobre as questões legais e a contextualização do problema.

No tópico relativo à conceituação, apontou-se que existiam muitas definições de comércio eletrônico, variando de acordo com a área em que ele é trabalhado. Foram selecionadas as áreas mais relevantes, considerando-se, de modo mais abrangente, o $e$ commerce como sendo "aquele que determina a capacidade de comprar e vender produtos e informações na Internet, entre outros serviços on-line". No ponto referente às questões legais, relatou-se que a natureza do direito comercial é consuetudinária, $\mathrm{e}$ que o comércio eletrônico estaria, dada a sua dinamicidade, forjando uma autoregulamentação. A despeito disso, grande parte dos países estaria editando leis sobre o

47 FORGIONI, Paula A. Apontamentos sobre aspectos jurídicos do e-commerce. Revista de direito mercantil, industrial, econômico e financeiro, ano XXXIX (nova série), São Paulo: Malheiros, p. 8182 jul./set. 2000 . 
comércio realizado na Internet, haja vista as vultosas somas de dinheiro oriundas das transações comerciais. Como aspectos legais controvertidos, enunciou-se a validade da assinatura digital e dos contratos realizados por meio eletrônico, a tutela ao consumidor, a proteção à propriedade intelectual, a tributação, entre outros. Na parte pertinente à contextualização do problema, situou-se o comércio eletrônico no panorama da globalização, salientando também que o comércio eletrônico não seria uma realidade à parte, mas uma faceta do mundo real com características peculiares, o que ensejaria um tratamento legislativo próprio nas situações que não encontram correspondência fora do ambiente virtual.

O capítulo subseqüente tratou da legislação sobre o comércio eletrônico no contexto internacional, mencionando o papel da ONU e seus organismos, a União Européia e o comércio eletrônico, o reflexo do e-commerce em um contexto global e a situação legislativa brasileira em relação ao e-commerce. No ponto referente à $\mathrm{ONU}$, foi destacado o papel da UNCITRAL, organismo criado para harmonizar as leis internacionais de comércio e que desenvolveu em 1996 a Lei Modelo sobre Comércio Eletrônico, destacando-se seus princípios e sua utilização como parâmetro em diversos países, elaborando em 2001 a Lei Modelo sobre Assinaturas Eletrônicas; apresentouse o estudo da UNCTAD, que evidenciou o valor das mensagens eletrônicas; mostrou o trabalho da OECD acerca do impacto social e econômico do e-commerce; tratou-se da $\mathrm{OMC}$, a qual se prestou a examinar as questões comerciais emergentes, bem como adotou a política de não-imposição de taxas alfandegárias no comércio eletrônico e, por fim, relatou-se a proteção da propriedade intelectual por parte da OMPI.

No tópico relacionado à União Européia, mencionou-se a criação de diretivas, fontes formais produzidas com o fito de harmonização legal no âmbito comunitário. Foi dado destaque à Diretiva 98/27/CE, que apresentou a questão do comércio eletrônico, e à Diretiva 2001/31/CE, pertinente aos aspectos legais da sociedade da informação, com destaque à proteção do consumidor. Coube menção também às diretivas relacionadas à privacidade na Internet e aos direitos autorais.

A esse tópico, seguiu-se análise sobre o reflexo do e-commerce em um contexto global, com uma breve descrição a respeito de algumas leis e projetos de lei pioneiros no mundo, como a Signaturverordnung - Alemanha, Legge 15 marzo 1997 - Itália, Electronic Communications Act - Grã-Bretanha, Loi .2000-230 - França, Proyeto de ley de servicios de la sociedade de la información y de comercio electrónico - Espanha, Resolução no 115/98 - Portugal, Resolución no 45 - Argentina, Ley n 27269 - Peru, Ley $n^{\circ} 527$ - Colômbia, dando-se destaque à vasta quantidade de leis norte-americanas sobre o tema, citando-se o Electronic Communications Privacy Act, Electronic Signatures and National Commerce Act e Millenium Digital Commerce Act.

Finalizou-se o capítulo com o estudo da situação legislativa brasileira. Muito embora não haver nenhuma lei sobre comércio eletrônico no Brasil até a redação final do presente trabalho, ressaltou-se a grande quantidade de projetos de lei em tramitação. Concedeu-se destaque ao Projeto de Lei $n^{\circ} 4.906 / 01$, oriundo do Senado Federal e que tramita na Câmara dos Deputados, estando a ele apensados os Projetos de Lei ${ }^{\circ} \mathrm{s}$ 1.483/99, 1.589/99, 6.965/02 e 7.093/02, da própria Câmara, que "dispõe sobre a 
validade jurídica e o valor probante do documento eletrônico e da assinatura digital, regula a certificação digital, institui normas para as transações de comércio eletrônico e dá outras providências". Também foi analisada a Medida Provisória $n^{\circ} 2.200 / 02$, medida provisória editada pelo Executivo com o fito de garantir a autenticidade, integridade e assegurar a validade jurídica dos documentos eletrônicos.

No último capítulo, a contratação eletrônica foi objeto de estudo, com a apresentação de noções sobre contrato eletrônico, espécies contratuais, contratos eletrônicos como contratos internacionais, os contratos eletrônicos e o Código de Defesa do Consumidor e a prova da contratação eletrônica.

No tópico referente às noções gerais, destacou-se a imaterialidade do meio em que o contrato eletrônico é realizado e o fato de ele não comportar uma inovação como tipo contratual: por exemplo, haveria contrato de compra e venda mercantil realizado por meio eletrônico, mas com os mesmos requisitos do contrato normal.

A seguir, foram mostradas algumas espécies de contratos que costumam assumir a forma eletrônica, seja através de compra e venda, seja através da prestação de serviços: jogos e apostas em loterias, serviços bancários, assinaturas de jornais, fornecimento de programas gratuitos, propostas de seguros, compra de veículos automotores, consultas de profissionais liberais, aplicações na Bolsa de Valores, cursos on-line, entre outras opções.

No tópico referente aos contratos internacionais, salientou-se que muitas vezes o contrato eletrônico transcende o direito interno por conter algum elemento que o caracteriza como contrato internacional, como partes oriundas de países diferentes ou local de fabricação e entrega do objeto da prestação situados em nações distintas daquela em que o proponente ou aceitante estão situados. Mostrou-se uma classificação dos contratos eletrônicos quanto à sua formação, colocando-se como contratos de formação instantânea quando há entre a aceitação e a oferta apenas o intervalo necessário para a propagação do sinal eletrônico, contratos de formação ex intervallo, quando ocorre intervalo considerável entre a oferta e aceitação e contratos de formação ex intervallo temporis, em que o intervalo de tempo comporta diversas negociações. Quanto ao momento da formação, discutiu-se a técnica a ser utilizada: extensão da ficção legal conferida aos contratos realizados por telefone, reputando-os como realizados entre presentes, ou se os contratos eletrônicos devem ser considerados como contratos feitos entre ausentes, já que as partes não se encontram fisicamente presentes durante a contratação. Quanto ao local de realização, o novo Código Civil, que disciplina o direito interno, reputa celebrado o contrato no local em que foi proposto: logo, se em uma transação virtual o proponente se encontra fisicamente em determinado Estado, este é considerado o local da conclusão. Todavia, segundo a LICC, se as partes residem em locais diferentes, como é o caso das transações internacionais, a obrigação constante do contrato é constituída no local em que residir o proponente: aplica-se, logo, o critério da residência. Entretanto, considerando os contratos eletrônicos como realizados entre presentes, eles dependem da lei do lugar onde foram contraídos.

Quanto ao Código de Defesa do Consumidor, procurou-se dispor no tópico a ele referente a sua aplicabilidade em relação ao comércio eletrônico. Apontou-se que 
ele é integralmente aplicado em seus princípios, fato reiterado inclusive pelo Projeto de Lei $\mathrm{n}^{\circ}$ 9.606/01. Entre os artigos mencionados, destacou-se o art. 30, referente ao dever de informação ao consumidor, em que a oferta deve ser clara e precisa. Exemplificou-se com a venda de eletrodoméstico através de portal de compras pela Internet. Outro artigo mencionado foi o art. 49, que diz respeito ao direito de arrependimento nos casos de venda à distância, e que se aplicaria nas transações virtuais pelo fato da enumeração disposta no caput, "especialmente por telefone e a domicílio" ser meramente exemplificativa. Apresentou-se o entendimento em sentido contrário de FÁBIO ULHOA COELHO, que considera o negócio através da Internet como sendo realizado dentro do estabelecimento do empresário, muito embora seja estabelecimento virtual, que se distinguiria do físico pelo fato de o deslocamento não ser feito no espaço. Foram traçadas linhas gerais sobre a teoria de COELHO a respeito do estabelecimento virtual e, por fim, pontuou-se que normalmente os contratos realizados pela Internet são contratos de adesão.

Para finalizar, estudou-se sobre a prova da contratação eletrônica. Reiterou-se que no Direito brasileiro prevalece o princípio da liberdade da forma, demonstrando que o contrato eletrônico tem validade jurídica, residindo a complexidade na comprovação em juízo do ato praticado, como o reconhecimento da integridade do conteúdo do documento, haja vista a possibilidade de alterações. Essa integridade poderia ser comprovada através da criptografia, certificação eletrônica e assinatura digital. Houve uma explanação acerca do método criptográfico, indicando como exemplos de contratações virtuais que se valem de criptografia para resguardar a segurança das operações bancárias e codificação de números de cartões de crédito.

Como se pode evidenciar, o objetivo foi partir de uma visão mais ampla para depois alcançar os temas específicos relativos ao comércio eletrônico, que englobam diversos ramos do Direito (embora sempre tenham, entre si, o liame do direito comercial). Através do trabalho com esses temas que se atingiu a meta principal: tornar mais claros para a sociedade os novos conceitos e as relações jurídicas que estão surgindo a fim de que haja conhecimento suficiente por parte de todos para que possam tutelar seus direitos caso se deparem com essas situações inéditas.

Após essa pesquisa, conclui-se que o tema tornou-se ainda mais amplo do que o era à época em que se engendrou seu projeto. Conforme foi mencionado nas discussões supra, a necessidade de regulamentação sobre o comércio eletrônico no Brasil é patente.

Para que se possa legislar de modo adequado, há o mister de se estudar o comércio eletrônico em um contexto global, com todos os precedentes e as leis pioneiras no mundo. Assim sendo, estudando-se a realidade brasileira, em conjunção com a realidade mundial, poder-se-á ter um domínio maior desse campo de conhecimento, fazendo com que haja efetiva proteção dos direitos que porventura possam ser violados - pois não se deve perder de vista que, embora as interações ocorram em um meio virtual, trata-se da tutela às pessoas reais que figuram nos pólos ativo e passivo dessas relações jurídicas.

Assim, o comércio eletrônico, cada vez mais forte em nossa realidade, precisa estar embasado pelo Direito de modo coerente com essa força. São milhões de negócios 
sendo travados diariamente por intermédio do e-commerce. E o direito comercial, um dos ramos de maior vanguarda do nosso Direito, está aqui para acompanhar essa extraordinária evolução do comércio mundial.

\section{REFERÊNCIAS BIBLIOGRÁFICAS}

Basic facts about the United Nations. New York: United Nations, 1998.

Diretiva 2000/31/CE do Parlamento Europeu e do Conselho. Jornal Oficial das Comunidades Européias, p. 2, 17 jul. 2000.

FOLHA DE SÃO PAULO. E-lei. São Paulo, Editoriais, 5 set. 2000.

Status of conventions and model laws. Disponível em: www.uncitral.org/en-index.htm. Acesso em: 2 nov. 2000.

Termo de Referência do Comitê Gestor ICP Brasil. Casa Civil da Presidência da República. Disponível em: www.planalto.gov.br. Acesso em 2 set. 2001.

ALTMARK, Daniel; QUIROGA, Eduardo Molina. Regimen jurídico de los bancos de dados in informática y derecho: aportes de doctrina internacional. Buenos Aires: Depalma, v. 5, 1991.

ASCENSÃO, José de Oliveira. Direito autoral. 2. ed. Rio de Janeiro: Renovar, 1997.

Direitos autorais na Internet. Verba Juris, ano II, n. 1, ago. 1999.

O direito de autor no ciberespaço. Disponível em: www.digital-forum.net. Acesso em 3 mar. 2000.

BAPTISTA, Luiz Olavo. Comércio eletrônico: uma visão do Direito brasileiro. In: Revista da Faculdade de Direito da Universidade de São Paulo. São Paulo: Serviço Técnico de Imprensa, v. 94, 1999.

BASSO, Maristela. Contratos internacionais do comércio: negociação, conclusão, prática. Porto Alegre: Livraria do Advogado, 1994.

BERGEL, Salvador Darío. Informática e responsabilidad civil. In: Informática y derecho: aportes de doctrina internacional. Buenos Aires: Depalma, v. 2, 1991.

BRASIL, Angela Bittencourt. Informática jurídica: o ciber direito. São Paulo: Loyola, 2000. . Ciberlex. Disponível em: www.ciberlex.adv.br. Acesso em 30 mar. 2001.

BRUNO, Marcos Gomes da Silva. Valor jurídico dos contratos eletrônicos. In: Revista Bonijuris, ano XIII, n. 457, dez. 2001.

BUENO, Márcio. A Internet e o Código de Defesa do Consumidor. O Estado do Paraná, Curitiba, Caderno Direito e Justiça, 19 nov. 2000.

CAMARGO, Denise. Burocracia eletrônica. Ecommerce, São Paulo: Segmento, ano 1, n. 2, jan./fev./mar. 2000.

CAVERSAN, Luiz. Comércio eletrônico vai ganhar lei liberal. Folha de São Paulo, São Paulo: Folha de São Paulo, Caderno Dinheiro, 4 set. 2000.

CHAVES, Antônio. Direitos autorais na computação de dados: software, circuitos integrados, videojogos, embalagem criativa, duração dos direitos conexos. São Paulo: LTr, 1996.

. Criador da obra intelectual: direito de autor, natureza, importância e evolução. São Paulo: LTr, 1995.

COELHO, Fábio Ulhoa. Curso de direito comercial. São Paulo: Saraiva, v. 3, 2000. Manual de direito comercial. 10. ed. rev. e atual. São Paulo: Saraiva, 1999. 
CORREA, Carlos Maria. El derecho informático en América Latina. In: Informática y derecho: aportes de doctrina internacional. Buenos Aires: Depalma, v. 2, 1991.

COSTA NETTO, José Carlos. Direito autoral no Brasil. São Paulo: FTD, 1998.

DAOUN, Alexandre Jean et al. Infojus. Seminário de Informática Jurídica. Realizado em 27 e 28 de outubro de 2000, Curitiba/Paraná.

FORGIONI, Paula A. Apontamentos sobre aspectos jurídicos do e-commerce. In: Revista de Direito Mercantil, Industrial, Econômico e Financeiro, ano XXXIX (nova série), São Paulo: Malheiros, jul./set. 2000.

GANDELMAN, Henrique. De Gutenberg à Internet: direitos autorais na era digital. 2. ed. Rio de Janeiro: Record, 1997.

GIANNANTONIO, Etore. El valor jurídico del documento electrônico in Informática y derecho: aportes de doctrina internacional. Buenos Aires: Depalma, v. I, 1991.

. Trasferencia electrônica de fondos y autonomia privada. In: Informática y derecho: aportes de doctrina internacional. Buenos Aires: Depalma, v. 3, 1991.

GLANZ, Semy. Contratos eletrônicos. In: Revista Brasileira de Direito Comparado. Rio de Janeiro: Instituto de Direito Comparado Luso-Brasileiro, 2000.

n. 757,1998 .

Internet e contrato eletrônico. In: Revista dos Tribunais. São Paulo: Revista dos Tribunais,

GOMES JR., Luiz Manoel. O controle jurisdicional das mensagens veiculadas através da Internet. In: Revista dos Tribunais. São Paulo: Revista dos Tribunais, n. 738, 1997.

GOMES, Orlando. Contratos. 11. ed. São Paulo: Forense.

GONÇALVES NETO, Alfredo de Assis. A disciplina jurídica do comércio eletrônico (ecommerce). Gazeta do Povo, Curitiba, 30 jul. 2000.

GRECO, Marco Aurélio. Internet e direito. São Paulo: Dialética, 2000.

GRINOVER, Ada Pellegrini et al. Código Brasileiro de Defesa do Consumidor: comentado pelos autores do anteprojeto. Rio de Janeiro: Forense Universitária, 1998.

HAMMES, Jorge Bruno. Internet, nomes de domínio, marca e nomes de comércio. Estudos Jurídicos, v. 33, n. 87, Unisinos, 2000.

KALAKOTA, Ravi; WHINSTON, Andrew B. Electronic commerce. A manager's guide. New York: Addison Wesley, 1999.

. Frontiers of electronic commerce. New York: Addison Wesley, 1999.

KORPER, Steffano; ELLIS, Juanita. The e-commerce book. Building the e-empire. San Diego: Academic Press, 2000.

KOSIUR, David. Understanding electronic commerce. Washington: Microsoft Press, 1997.

LAMBERTERIE, Isabelle. Contratos informáticos. In: Informática y derecho: aportes de doctrina internacional. Buenos Aires: Depalma, v. 4, 1991.

LINHARES, Marcel Queiroz. Venda de veículos novos através da Internet: reflexos no campo da exclusividade inerente à concessão de veículos automotores. In: Revista de Direito Mercantil, Industrial, Econômico e Financeiro, ano XL (nova série). São Paulo: Malheiros, jan./mar. 2001. LYNCH, Daniel C.; LUNDQUIST, Leslie. Dinheiro digital: o comércio na Internet. Trad. Followup Traduções e Assessoria de Informática. Rio de Janeiro: Campus, 1996.

LUCCA, Newton de; SIMÃO FILHO, Adalberto (org.). Direito e Internet - aspectos jurídicos relevantes. Bauru, São Paulo: Edipro, 2000. 
MAISONNAVE, Fabiano; LOUZANO, Paula. O futuro sombrio da Internet. Folha de São Paulo, São Paulo, Caderno Mais!, 5 mar. 2000.

MARQUES, Cláudia Lima. Normas de proteção do consumidor (especialmente no comércio eletrônico) oriundas da União Européia e o exemplo de sua sistematização no Código Civil Alemão de 1896. In: Revista de Direito Privado (coords. Nelson Nery Júnior e Rosa Maria de Andrade Nery) São Paulo: Revista dos Tribunais, v. 4, 2000.

MARTINS, Guilherme Magalhães. Contratos eletrônicos via Internet: problemas relativos à sua formação e execução. In: Revista dos Tribunais. São Paulo: Revista dos Tribunais, n. 776, 2000. MATTE, Mauricio. Internet - comércio eletrônico: aplicabilidade do Código de Defesa do Consumidor nos contratos de e-commerce. São Paulo: LTr, 2001.

MORAES, Maria Antonieta Lynch de. Possibilidade de caracterização do site na noção de estabelecimento comercial na Lei Complementar $n^{\circ}$ 87/96. Revista de Direito Privado (coords. Nelson Nery Júnior e Rosa Maria de Andrade Nery). São Paulo: Revista dos Tribunais, v. 9, 2001.

MOTTA, Carlos. Centro Brasileiro de Estudos Jurídicos da Internet. Disponível em: www.cbeji.com.br. Acesso em 15 set. 2000.

MOUGAYAR, Walid. Opening digital markets. 2. ed. New York: McGraw Hill. 1998.

OLIVO, Luis Carlos Cancellier Olivo. Direito e Internet: a regulamentação do ciberespaço. Florianópolis: UFSC, 1998.

PAESANI, Liliana Minardi. Direito de informática: comercialização e desenvolvimento internacional de software. São Paulo: Atlas, 1997.

PAREDES, Marcus. Violação da privacidade na Internet. In: Revista de Direito Privado (coords. Nelson Nery Júnior e Rosa Maria de Andrade Nery). São Paulo: Revista dos Tribunais, v. 9, 2001.

PEREIRA, Alexandre Libório Dias. Comércio electrónico na sociedade da informação: da segurança técnica à confiança jurídica. Lisboa: Almedina, 1999.

. Direitos de autor, códigos tecnológicos e a lei milênio digital. Boletim da Faculdade de Direito, Universidade de Coimbra, v. XXV, 2000.

. The protection of intellectual property in the legal framework of electronic commerce and the information society. Boletim da Faculdade de Direito, Universidade de Coimbra, v. LXXVI, 2000.

PIMENTA, Eduardo S. Código de Direitos Autorais e Acordos Internacionais. São Paulo: LEJUS, 1998.

ROCHA, João Luiz Coelho. Contratos e obrigações virtuais. In: Revista de Direito Mercantil, Industrial, Econômico e Financeiro, ano XXXIX (nova série). São Paulo: Malheiros, out./dez. 2000.

SÁNCHEZ, Guilhermo Ormazábal. La prueba documental y los médios e instrumentos idoneos para reproducir imagenes o sonidos o archivar y conocer dados. Coleccion Ley de Enjuiciamiento Civil 2000. Madri: La Ley, 2000.

SANTOS, Maria Cecília de Andrade. Contratos informáticos - breve estudo. Revista dos Tribunais, São Paulo: Revista dos Tribunais, n. 762, 1999.

SCHOUERI, Luís Eduardo. Internet: o direito na era virtual. 2. ed. Rio de Janeiro: Forense, 2001.

SOARES, José Carlos Tinoco. Abuso de direito pelo uso de nomes de domínio na Internet. In: Revista dos Tribunais, São Paulo: Revista dos Tribunais, n. 786, 2001. 